BULLETIN OF THE GEOLOGICAL SOCIETY OF AMERICA

VOL. 21, PP. 249-284, PLS. 6-17

JUNE 15, 1910

CACOPS, DESMOSPONDYLUS; NEW GENERA OF PERMIAN VERTEBRATES ${ }^{1}$

BY s. W. WILLISTON

(Presented in abstract before the Paleontological Society Dec. 30, 1909)

\title{
CONTENTS
}

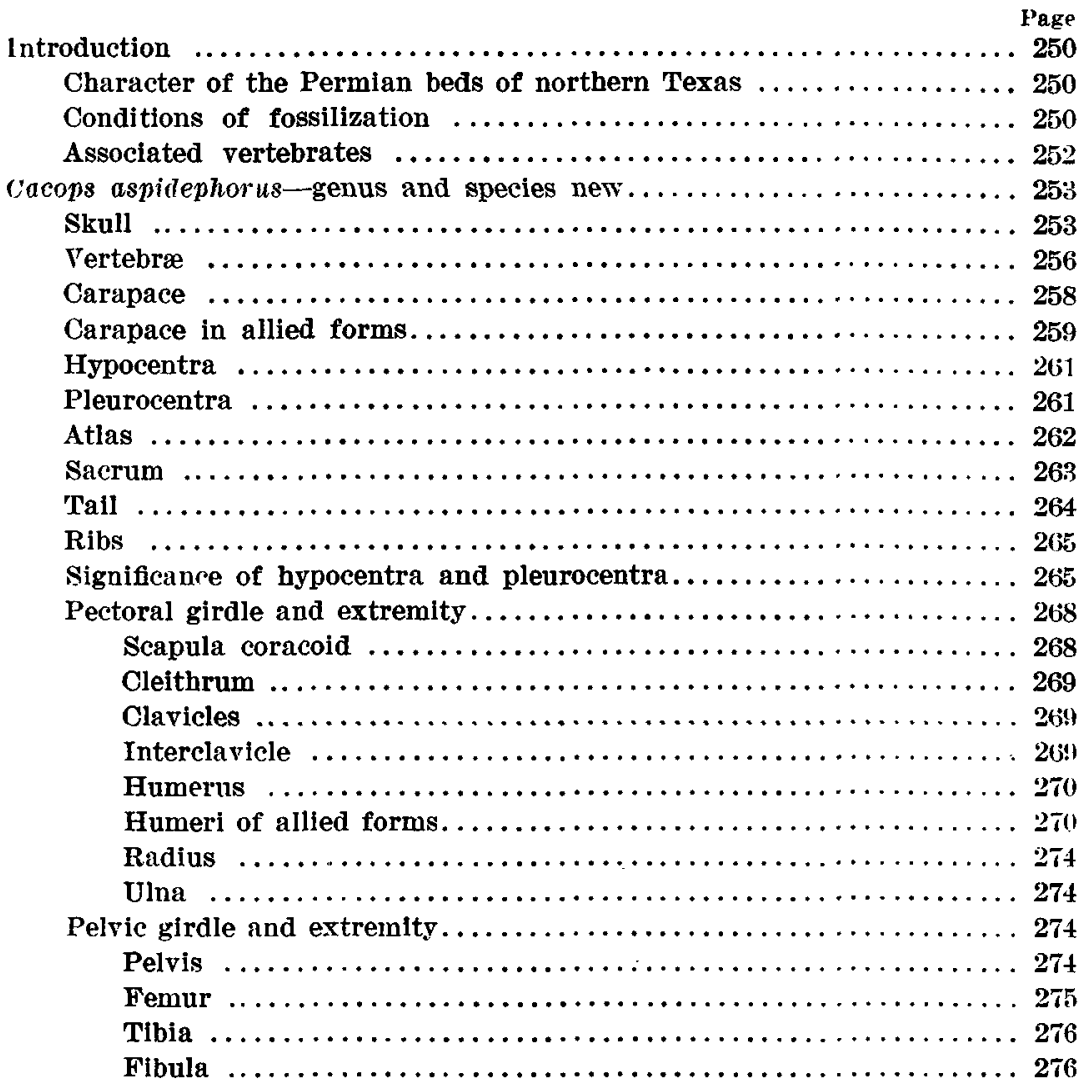

1 Manuscript received by the Secretary of the Geological Society April 23, 1910.

(249) 


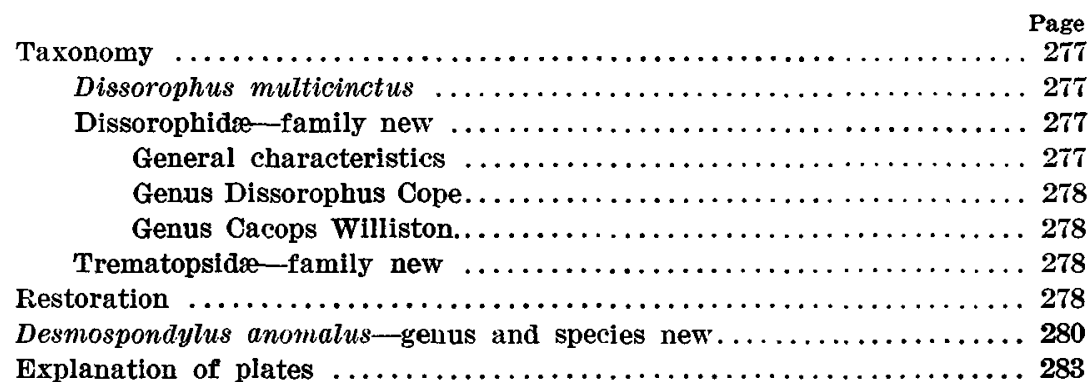

INTRODUCTION

OHARAOTER OF THE PERMIAN BEDS OF NORTHERN TEXAS

In a field experience dating from $\mathbf{J}$ uly, 1874 , in nearly every known vertebrate horizon of North America, I know of no beds so difficult of exploitation as those of the Permian of northern Texas. As a rule the vertebrate fossils are found more or less broken and weathered, scattered about on the sloping exposed surfaces. Occurring as the bones do, almost invariably concealed beneath a thin or thick covering of cemented matrix, so like the color and form of the countless millions of nodules, it is only when they have been broken up and weathered by exposure that the slight colorational differences presented by the fractured surfaces distinguish them. It thus happens that by far the larger part of the material se('ured, especially that of the smaller aninals, is more or less fragmentary in character, though fortunately preserved from rapid disintegration by the covering of more or less intractable matrix.

\section{CONDITIONS OF FOSSILIZATION}

The middle portion of the deposits is to a large extent free from nodular concretions. presenting smonth, clean surfaces of red clay, especially inriting to the collector. But. unfortunately, it is these attractive deposits which are the most barren of fossils. I have searched patiently orer such beds for many successive hours without being rewarded by a single fragment of a fossil; and it is for this reason that one, after a little experience, learns to avoid these clay deposits, or gives them but scant attention. Nevertheless it is in these "barren" deposits that the prizes of the Texas Permian are to be sought. When fossils do occur in them. they usually are excellently preserved and largely frec from the exasperating matrix. Professor Case has observed that but one or two specimens may be expected from these clay beds in a season's work, and 
he is not far wrong in his estimate. Ard it was one of these prizes which was discovered by Mr. Paul Miller, of the University of Chicago Expedition of 1909, between the ralley of Indian Creek and the Wichita River, about 5 miles west of the Vernon roarl. A large quantity of small bones weathered out and lying in a small gully led to the detection of a bone bed or "quarry" that is without equal in the history of the "Texas Permian exploration. The clay lying over the mass of bones protruding from the hillside was entirely free from nodular masses, and, with the exception of a few ounces of bone fragments a half mile away, not another indication of a fossil was discovered in the adjacent exposures covering several hundred acres. The clay was excavated down to the level of the bones, and the bones were then removed in large clay blocks securely bandaged. It was found quite inexpedient to attempt the removal of the bones from the matrix in the field. Not only was the thin adherent matrical covering of the bones so perfectly like the clay in appearance that to distingrilish the bones from fragments of the indurated clay when loosened required the most minute examination, but the interlacing of the numerous skeletons in the mass prohibited the attempt to separate them in the field. Indeed, in the laboratory the only safe way to prevent the loss of small bones and fragments of bones when dissociated is to dissolve the clay in water. As it was, with the inadequate tools at our command near the close of the season, the complete excavation of the bed was not atlempted, but will be resumed the present season by Mr. Miller, when it is confidently expected that much additional material will be secured.

The skeletons lay in a narrow deposit about 5 feet in width and of unknown extent throughout a thickness of about 2 feet, and apparently on a sloping horizon. They are almost invariably found lying on the rentral side, and for the most part with the members undisturbed, save that in some cases the phalanges of the feet are more or less scattered about, and the tail or whole limbs may be dislodged. Many of the bones have a very thin layer of cemented clay covering them; others are more or less cemented together in nodular masses. It is very evident from the character of the deposits and the position of the bones that the skeletons had suffered but little disturbance after death; that the creatures had for the most part died peacefully in a stagnant, perennial pool of water, successive generations piled upon each other in layers.

I estimate that. so far. there is evidence of at least 50 or 60 skeletons in the deposit. From the loose material recovered from the surface I count over 50 femora, nearly as many humeri and corresponding girdles, with large quantities of the vertebræ. In the blocks containing the thickly aggregated skeletons secured, there are probably representatives 
of at least as many more, judging by the two or three blocks that have been so far worked out. How many more remain to be secured the present season I can not even conjecture. We anticipate as much more material as we already have.

\section{ASEOCIATED VERTEBRATES}

Not many different kinds of animals are represented by the remains so far examined. The great majority of the skeletons belong to the genus Varanosaurus Broili. Another genus of reptiles, very clearly new to science and of about the same size as Varanosaurus-that is, 4 feet in length-is represented by fewer remains, but still sufficient, it is confidently beliered, to furnish the complete structure of the creature. So far, of this form, the complete hind legs and feet, pelvic girdle, and tail have been worked out, and two skeletons are running into the block matrices. Its restoration and description will be published as soon as possible. A third genus of reptiles, also new to science, represented so far by a femur, which is described and figured (plate 16, figure 5) in the present paper as Desmospondylus, was also found. All the amphibian remains so far obtained belong to the present genus Cacops, and consist of the nearly complete skeleton shown in the restoration in plate $1 \%$, together with another skeleton less complete, portions of two other skeletons and skulls, and rarious remains of less moment found in the topmost layers. I doubt not that the present material on hand will disclose additional skeletons of this genus more or less complete. One skeleton of Varanosaurus. complete from the tip of the tail to the back of the skull, has been completely worked out and figured in 20 plates. An additional skull of another skeleton still leaves some details to be determined, doubtless to be found in other skeletons and skulls yet in the matrix. The full description, with figures and plates of the skeleton of this form, will follow the present paper within a year.

The skeleton of Cacops, as shown in plate 17, is composed exclusively of one specimen, with no more plaster in its construction than was necessary to cement the freshly broken parts in its preparation, save of many of the phalanges, as is described further on. The specimen was not only prepared hy Mr. Miller, but was skilfully mounted by him in the course of a couple of months' labor. It is doubtful whether another type of fossil vertebrate animal of the size of this is represented by as complete material as is Cacops aspidephorus. 


\section{CaCops aspidephort's-Genus and Species New}

\section{SKULL}

(Plates 6, 7, 8)

Two skulls, nearly complete, and portions of two others have so far been recovered from the matrix. Of these the one in the mounted skeleton was quite complete, but suffered slightly at the front extremity in its collection. The best specimen, however, the one from which the following description has been drawn, was a skull quite complete, attached to another skeleton, from which the posterior end of the mandibles only was lost in collecting. This skull is slightly smaller than the mounted one and had suffered very little distortion. It has been freed from every particle of matrix, even that of the brain and nasal cavities. Unfortunately, in none of the specimens has it been possible to determine the sutures, in part because of the complete ossification of the bones; in part, perhaps, because the removal of the thin investing matrix has obliterated whatever indications of them might have been present. The dermal surface is everywhere rugose, with small, irregular pits and ridges.

The skull is broad and depressed, broadest opposite the posterior part of the orbits, with a gentle, perhaps somewhat irregular, convexity on the sides. The epiotics project backward strongly, leaving a deep concavity in the middle behind. The nares are large, oval in outline, directed upward, forward, and outward, broadly separated in the middle, and approaching closely the margin of the maxillæ. The orbits are large, subcircular in outline, the opening looking obliquely upward. Near the middle of their front margin the border is angularly thickened, descending in a steep declivity outwardly. In the middle posteriorly, also, there is a similar, but more angular, thickening, which extends back as a ridge to form the lateral margin of the cranial table, overhanging the otic cavity posteriorly. Almost continuous with the upper orbital margin, there is another elevated ridge running backward and outward to join the lateral border over the middle of the otic cavity. Between these two ridges there is a triangular space of considerable size, more or less depressed in its middle. The least distance between the orbits, near their middle, is but little or no more than one-half the lateral diameter of the orbit. The large parietal opening is located about one-third of the distance between the hind borders of the orbits and the occipital margin in the middle. Just in front of the concave hind border of the table the margin is elevated into a prominent rugose crest or ridge, highest in the middle, possibly for the attachment of nuchal muscles. The cranial table in front of 


\section{4 s. W. WILLIS'TON-NEW GENERA OF PERMIAN VERTEBRATES}

this transverse rugosity, and between the slightly elevated lateral margins, is flat or gently concave.

On the sides posteriorly there is a large cavity, with an angulated slitlike opening at its bottom, forming a false temporal fenestra, which doubtless is merely a greatly enlarged and closed otic notch. ${ }^{2}$ It is bounded above by the heavy overhanging lateral border of the cranial table. The epiotic angles, produced into long horns, instead of ending freely, as in other Stegocephala, turn directly downward to fuse with the quadrate below, inclosing what would otherwise be a simple notch into a large fossa and opening. Its whole exterior and outer surface is roughened like other parts of the skull. The cavity thus inclosed extends angularly at its upper anterior angle to within about 20 millimeters of the middle of the hind border of the orbit and is smooth throughout. At its bottom there is a thin, flat, angular plate, attached to the lower anterior inner side of each epiotic horn, projecting upward and forward to an acute angle, leaving a narrow, slitlike perforation above connected with another in front reaching the lower part of the cavity, angularly dilated at the upper anterior part. Close to the anterior border of this plate, and near its upper angle, is the projecting end of the stapes, as shown in plate 8 , figure 1 . The upper margin of the perforation in front is formed by a narrow descending plate from the rugose upper border of the cavity. The front wall of the cavity slopes backward from the upper angle to a little above the quadrate articular surface; its smooth wall looks obliquely upward, backward, and outward. It seems probable that this carity, as thus bounded, was closed by a tympanic membrane, against which the continuation of the stapes abutted.

The precise limits of the epiotic process are not certain, but a distinct line is evident on one side, indicating sutural attachment with the quadrate along the posterior side of the platelike expansion and to within a short distance of the articular projection. This, I am aware, is an unusual position for the quadrate, with the ear-slit or opening above and in front of it, but there can be no other interpretation of the structure. The quadrate is well ossified below, fused with the extremity of the pterygoid on the inner side and with the quadrato-jugal in front below.

The occipital surface of the skull has, in the middle, a smooth, steep declivity, with the small foramen magnum at the bottom, not more than 5 millimeters in diameter. The high rugosity of the posterior border of the cranial table overhangs slightly this declivity, forming a fossa into which doubtless were inserted the strong neck muscles. Just outside of

- A closed otlc notch is not unknown among Stegocephala. See Woodward, ProceedIngs of the Zoological Soclety, 1904, p. 170, plate xi. Capitosaurus stantonensis Wood. 
cach condyle there are the usual two cranial foramina at the base of the paroccipital processes, which extend outward, joining the epiotic on the under side and turming downward to terminate at or near the upper posterior corner of the quadrate. Between this paroccipital process and the roof, at each side, there is a moderately large post-temporal vacuity leading into a deep cavity just inside the "tympanic" rim of the ear cavity and below the roof of the skull.

The structure of the under side of the skull, while not departing far from the usual stegocephalan type, is somewhat remarkable. The palatal cavity as a whole had a high arched roof, with a slender, almost vestigial. parasphenoid dividing the large pterygoidal vacuities so characteristic of the amphibia. The internal nares are larger than the external ones, situated either side close to the teeth, with their front margin almost below the hind margin of the external nares. On the inner side of each there is a stout, conical, recurved tooth, about 10 or 12 millimeters in length, and another like it is situated near the posterior margin of the orifice, not far from the maxillary teeth. These are the only teeth located on the palatal surface. The palatines, or conjoined palatines and pterygoids, on each side posteriorly and internally to the nares slope strongly upward. In the middle in front the vomers or anterior end of the parasphenoir is about 15 millimeters in width where it joins the palatine shelf, narrowing to about 4 where it joins the rhinencephalic chamber. Posteriorly the arrangement of the basicranial bones is very similar to that of Trematops or Eryops. The ossified basisphenoid sends downward and outward a stout basipterygoid process to join the pterygoids on each side, the juncture indicated by a thickening as in Trematops. Outwardly the pterygoids form a vertical plate. probably with the conjoined epipterygoids, reaching to the cranial wall, save for a small vacuity near the roof, leading into the deep temporal cavity under the roof, into which the posttemporal vacuity also opens, a cavity open below back of the pterygoids between the basicranial bones and the posterior wings of the ptervgoids. In the middle the parasphenoid continues forward from the basisphenoid as a slender rodlike bone nearly to the flat anterior end. For a short distance it forms a high bridge, above which in front is the inferior opening of the parietal foramen. For the larger part of its distance, however, it is closely united as a thick ridge to the lower side of the elongated rhinencephalic chamber (see plate 7 and plate 8 , figure 1). Between this chamber and the closed brain-chamber behind there is a large orifice on each side for the escape of the optic nerves. This elongated arched chamber has its anterior borders also free and curred a little back of the anterior margin of the orbits. In front of this the roof of 
the skull has been somewhat pressed down upon the palatal bones, but there was evidently in life a high cavity for the nasal region, in which are various indeterminate bone remains, doubtless the ethmoidal and turbinate. A little in front of the basisphenoid the pterygoids give off a rounded or subangular process much as in the allied forms, narrowing the opening of the infratemporal fossa, which is broad and deep behind, where its thin upper posterior roof forms the anterior inferior wall of the otic cavity.

The basisphenoid is concave in the middle; on either side it has a flattened basisphenoid process, as in Trematops, directed downward and backward, underarching a rather deep fossa. Opposite these on either side is the root or base of the pointed, stylelike stapes, which is directed outward and backward to terminate, as already described, at the upper angle of the quadrate, in the auditory vacuities. Whether or not it has a foramen at its base $I$ can not say. Above and in front of this, turned upward to reach nearly to the inner surface of the superior tympanic ridge, is the proötic bone.

A comparison of the structure of the basicranial region with that of Trematops shows great similarity, quite confirming my suggestion that the pseudotemporal vacuity is in reality merely the closed otic notch for the opening of the external ear. The opening in Trematops, however, is far smaller than in Cacops, and extends somewhat further forward toward the orbit. The small size of the parasphenoid in the present genus also explains its apparently entire absence in Trematops, though it is not improbable that the rhinencephalic canal in Trematops, were it preserved complete in the type specimen, would show the remains of the parasphenoid coalesced with it as in Cacops.

The maxillary teeth in Cacops are all small and of nearly uniform size, in an uniform closed series. I count about 20, but it is possible there may have been a few more.

The mandible is remarkable for its slenderness. Posteriorly it has a broad expansion, but the ramus from the middle of the orbits forward is slender. A deep fossa is present in front of the condyle, and the median symphysis in front is a little expanded. It has apparently the same number of teeth as in the maxillæ, and all, like them, are of uniform size.

\section{VERTEBRA}

(Plate 9)

The vertebral column of the mounted skeleton was apparently quite complete as it lay in the matrix in association with skull and limbs. In 
the removal of the thin incrusting matrix, however, a few of the pleurocentra of the anterior vertebræ and some of the small elements of the tail were lost, notwithstanding the most scrupulous care. Of these, only the possible pleurocentra of the atlas and the dorsal elements of the first 5 or 6 caudal vertebræ have any morphological significance; future preparations of other skeletons yet contained in the matrix will doubtless complete even these small details. The column as found was continuous from the skull to the tip of the tail, without break, save that the last few caudal vertebræ were slightly angulated from the rest of the series. The presacral vertebræ had a gentle, sinuous curve, with the convexity to the right as far back as the end of the dermal carapace, to the left from thence to the sacrum. There is also a slight vertical sinuosity in the same regions, convex above anteriorly, below posteriorly. These curvatures seemed so normal that no attempt has been made to reduce them in the mounted skeleton, and I have figured the column as it lay. A slight pressure to the left has crowded the ribs upward on that side and downward on the opposite side, but to a very slight extent only. The perfect union of the different elements, at least as far as the beginning of the chevron caudal vertebræ, removes all possible doubt as to their number and relations-21 presacral, 2 sacral, 6 pygals, and 15 or 16 chevron caudals. The spines, save those of the first 2 vertebræ, are of nearly uniform length throughout the carapacial series, 15 in number, a trifle longer perhaps in the anterior and middle region, and a little more slender in the last 3 or 4 . Those of the free presacral vertebræ are progressively shorter and less stout. Throughout the series covered by the carapace they are slightly thickened at the upper end, with the anterior and posterior margins thinned, and with a lateral ribbed thickening on each side near the middle, as though for the support of the terminal expansion. Covering the top of each spine there is a rooflike expansion, wider in the middle and narrowed at each lateral end. Their sides slope downward at an angle of about 45 degrees to the full width of the superincumbent dermal scutes. The anterior margin of these plates is uniformly beveled for articulation with the posterior margin of the superincumbent intercalated dermal scute. The posterior beveling is much broader in the middle. Presumably these expansions are outgrowths from the top of the spine, cartilaginous in origin, but of this I do not feel entirely assured, since in every case where I have removed them I have found what appears to be a sutural surface, and the top of the spines is rounded on the margin, with an extrant angle between it and the plate. The surface of these expansions is smooth, both above and below. The narrowed outer extremities are either rounded or with a slight emargination. The first 
of these expansions, that of the second rertebra, is small, subtriangular in shape, with rounded corners, and appears not to have been covered by a dermal scute. The second expansion is larger, becoming broader behind, and is covered, on its posterior part only, by the first dermal scute. The posterior end of the carapacial series tapers more gradually than does the anterior to a narrower extremity, and like that has, apparently, no dermal plate over the last of the series, the penultimate spinal expansion supporting the posterior margin of the last dermal shield. Throughout this series the thinned expansions of the spines above, anteriorly and posteriorly, touch each other in the present curved condition of the column. In the most anterior part of the column, however, the hypocentra are slightly separated, with one longer interval, producing a slight convexity of the series below. It thus seems certain that the position in which the column was found, and which has been retained in the mounted specimen, was a normal one for the living animal; that is, with a gentle convexity antero-posteriorly of the carapace, and a slight concavity below. Nor would it have been possible for the living animal to have fully straightened out the column without actually dislocating the zygapophysial articulations. A slight lateral bending was possible in life, as shown by the position in which the bones were found; but even this could not have been extensive in the front part, since the free dermal plates. which glided smoothly over the fixed spinous expansions would have met each other at their lateral extremities, if the curvature was at all decided. Back of the carapace, however, a greater flexibility was possible, since the zygapophyses here are somewhat larger, and the free spines were separated above by a greater interval.

\section{OARAPAOE}

(Plate 9 and plate 12, figures 5, 6)

The dermal plates are of nearly uniform length, increasing slightly in expanse to the middle of the series-that is, at the summit of the dorsal convexity. Each fits accurately and closely over the contiguous borders of the adjacent spine roofs, separated from each other by a space of 1 or 2 millimeters. It is evident, from the structure of the spine expansions with the greater beveling in the middle behind, that the chief motion was at the anterior part of each dermal plate. The upper surface of these plates is slightly irregular, with shallow depressions or pits, the margins in front and behind parallel, with a slight obliquity backward; their outer angles are slightly rounded, and their outer, thin borders are nearly straight, or with a slight emargination. Each of these dermal plates is composed of two elements, a median longitudinal suture being evident in 
many of the shields. In the middle of each above there is a shallow groove bordered on each side by a slight elevation.

In the structure of the dorsal shield or carapace the genus is identical with Dissorophus, save that the carapace of the latter genus is very much more extensive, covering practically the whole of the dorsal side of the animal and probably extending further back. Furthermore, in Dissorophus the anterior shield is very large, covering several vertebræ, very much like the anterior shield in certain armadillos. That these differences in the carapace, together with others of the skeleton, as shown in an excellent specimen of Dissorophus in the University of Chicago collections, which will be fully figured later, are not due to age, is evident from the close correspondence in all skeletal characters between several specimens found associated in the present matrix. These differences will be summarized in the taxonomic discussion on a later page.

\section{OARAPAOE IN ALLIED FORMS}

Most remarkably similar are the dorsal shields of the genus Aspidosaurus Broili, which in other respects, so far as the skeletal characters are known in the rather fragmentary type, resembles so closely the present form that $I$ was for a long time almost assured of their identity, and this opinion was also shared by Doctor Broili, to whom I sent for comparison photographs of the drawings of the plates illustrating the present paper. But a careful study, not only of the figures and descriptions given by Broili, but also of a fragmentary specimen in our present collections, which must be identified as conspecific with the genotype of Aspidosaurus, quite convinces me, as it has also Doctor Broili, of the generic distinction between the two forms.

In Aspidosaurus there is but a single dermal expansion over each spine, apparently coössified or continuous with the top of the spine, which overlaps the preceding one like shingles on a roof. Or, as Broili has stated it:

"Diese Hautverknöckerungen treten nun in innige gegenseitige Verbindungen insofern sich dieselben aufeinanderliegen und zwar immer die folgenden auf die vorausgehende Ossification, wodurch das Gänze gewisse Aehnlichkeit mit den First eines Hauses gewinnt. Diese eigenthümliche Schutzapparat fällt noch besonders durch seine Skulptur auf, welche die nämliche kräftige Ausbildung zeigt, knötchenartige durch Leistchen verbundene Auschwellungen, wie der Schädel. Die Unterseiten dieser Hautverknöckerungen sind glatt, nur ihrer seitllchen Ränder weisen leichte Einkerbungen auf."

Of the specimen above mentioned I give figures (plate 10, figures $2, a$, b) showing this very characteristic difference. It is seen that the broad

- Paleontographlca, vol. li, 1904, p. 42. 
spinous expansions overlap like shingles the ones preceding. The roof also differs in the greater angularity of the ridge, the sides sloping at a greater angle, while in Cacops there is a median depression or shallow groove, and the lateral plates are more convex. The spines supporting these plates are much more expanded above than is the case in Cacops. From Broili's figure of the type of Aspidosaurus it is not certain that the otic notch is inclosed by bone, as in the Dissorophidæ, though the emargination shown would suggest that such may be the case.

A specimen recently described by Case $^{4}$ and referred doubtfully to Zatrachys apicalis is in all probability a species of Aspidosaurus, a genus apparently overlooked by the author. The author described the carapace as having overlapping plates, with great angularity, apparently quite as in the specimen herewith figured, and as in the type specimen figured by Broili. If the specimen be conspecific, or at least congeneric with Aspidosaurus, as I doubt not, then an additional generic character is furnished by the ribs. These have an elongate hooklike process directed upward and backward over the succeeding ribs, quite unlike the structure in Cacops.

Altogether the differences presented by Aspidosaurus are so fundamental that I believe Broili was justified in separating the genus from $D i s-$ sorophus on the character of the carapace alone. If so, then certainly Cacops can not be united with Aspidosaurus, even though the size and extent of the carapacial development is much more like that of this genus than of Dissorophus. Possibly the Aspidosaurus type of roof has been derived from that characteristic of the Dissorophidæ by the anchylosis of the dermal scutes with the superior expansions of the spines, but even such a difference as this is of generic importance.

Other genera of temnospondyles are known to possess similar carapacial developments. Euchirosaurus, from the Lower Permian of France, has a broad dilatation of the spines above, though not platelike. Very similarly expanded spines I have seen in specimens from the Texas Permian, but have been inclined to refer them to the basal caudal region of Eryops.

The structure of the dorsal expansion of Zatrachys is very imperfectly known, unless, indeed, Case was right in referring his species apicalis to that genus. The vertebræ are unknown in the type species. In another species, referred to the genus by Cope later, the real $Z$. apicalis, he described the spines as follows: "The summits of the neural spines are expanded and the superior faces of the expansion are tubercular and have

- Bulletin of the American Museum of Natural History, vol. xxili, 1907, p. 665. 
a median prominence. The expansions are sometimes large, resembling the dermal bones of the crocodiles, and in that case the median prominence is a keel. On the smaller expansions the latter is a mere apex. There are narrow, flat bones which I suppose to be neural spines, which are ornamented with innosculating ridges." " These characters agree better with a spine figured and described by Case as Zatrachys crucifer Case, ${ }^{6}$ the type of which I have examined. This is of much larger size, and is in the shape of a cross, the median projecting piece above and the upper surface of the transverse arms are deeply pitted-a radically different type from that of either Aspidosaurus or Cacops. The description of the skull seems to preclude the possibility of the genotype being congeneric with Cacops aspidephorus.

\section{HYPOCENTRA}

(Plate 9, plate 12, figure 7, and plate 14, figure 12)

The hypocentra, like the arches, are of nearly equal size and extent throughout, rather strongly and smoothly convex from side to side, gently concave antero-posteriorly. The second to the eighth back of the atlas have, on each side, near the upper angle posteriorly, a facet or protuberance for the capitular articulation of the rib. The first hypocentrum back of the atlas is smaller than the succeeding ones; it is shorter and has more acute lateral margins, and is, apparently, without facets for the capitular articulations. The second hypocentrum is also somewhat smaller than the succeeding ones, but is provided with a parapophysial protuberance on each side.

\section{PLEUROCENTRA}

(Plate 9 and plate 12, figure 5)

Of the first four vertebræ back of the atlas the pleurocentra were not recovered; they doubtless had dropped ont of their places and were not recognized in the matrix, since a slight depression of this part of the column had loosened all the elements somewhat. However, in the connected series places for them are shown with articulations indicating but little variation in size from that of the following ones. In size the pleurocentra of the remaining vertebræ are nearly uniform, perhaps slightly longer anteriorly than posteriorly. Each articulates broadly with the poterior side of the pedicel of the neurocentrum, and, less extensively, with the anterior side of the following neurocentrum, as shown in plate

\footnotetext{
- Proceedings of the American Philosophical Soclety, vol. xvil, 1881, p. 623.

- Journal of Geology, vol. xi, p. 399.
} 
12, figure 5, and by the narrowed lower extremity with the posterior superior margin of the hypocentrum, fitting into the angular space between the adjacent neurocentra. The large flat sutural surface for union with the preceding neurocentrum indicates a close, firm union, while that with the succeeding neurocentrum and hypocentrum is more rounded. The pleurocentrum of the first presacral vertebra is narrower than the preceding one. The pleurocentra of the two sides of each vertebra are closely approximated in the middle above a small concavity on the upper side of the hypocentrum, leaving in the articulated parts a persistent notochordal canal.

The zygapophyses are stouter in the free or lumbar portion of the column than in that part covered by the carapace, as would be expected, since the comparative rigidity of this part prevents extensive motion of the individual vertebræ upon each other. Their articular surfaces look uniformly upward and inward, and downward and outward, at an angle of something less than 45 degrees.

The diapophyses arising from the neurocentra increase rapidly in vertical extent of their rib attachment as far as the eighth, the border continuous with the parapophysial projection on the hypocentra. The ninth suddenly decreases in width, with a wide interval between its lower end and the hypocentrum, which has no parapophysial facet. From the ninth the transverse processes are narrower, with the extremity for rib articulation of but moderate extent. Throughout the series the processes are directed almost transversely outward, with the upper nearly horizontal margin a little thickened and rounded; the upper margin arises a little below the zygapophyses anteriorly, a little lower down posteriorly. The rib margin is straight or gently sinuous from above downward, thinned below and slightly emarginated, ending, as has been described in the first eight, in apposition with the parapophysial facet on the hypocentra. The lower end of the rib margin is considerably in advance of the upper. Beginning with the ninth, where the ribs become single-headed, the transverse processes are of nearly uniform width, the articular surface for the rib placed obliquely to the vertical line. Beginning with the seventeenth rertebra, the first behind the carapace, the diapophyses shorten rapidly, becoming almost sessile in the last two, in which the rudimentary ribs seem to be anchylosed to their extremities.

\section{ATLAB}

The atlas was preserved in this specimen in place. It is somewhat eroded and does not seem to differ from a better preserved specimen belonging to the closely related genus Dissorophus, which I have figured in 
plate 14, figure 11. This vertelra seems to be a single element, though doubtless it is composed of coalesced hypocentrum and neurocentra; but I can distinguish no sutural lines. The anterior surface shows two facets for articulation with the occipital condyles. On the posterior side the body has a deep concavity, pierced above its middle by a small notochordal foramen. The neuropophyses are simple processes, of nearly uniform width, and flattened; they lie closely in apposition with the sides of the spine of the second vertebra. The same condition is found in Eryops and Trematops, and is doubtless the usual structure of the atlas in the rhachitomous amphibians. Back of the neurocentra $I$ find no articular surface for the attachment of pleurocentra, though the anterior border of the next-vertebra seems to indicate the presence of small pleurocentra.

The real composition of the atlas of the rhachitomous amphibiansfor I doubt not that the vertebra is homologous with the atlas of the higher vertebrates-is a matter of some importance. If there be pleurocentra between the atlas and second vertebra, then we have the same structure as exists in the reptiles and higher vertebrates, the atlas composed of hypocentrum and neurocentra, the pleurocentra separated to unite with the axis. Against this interpretation, however, is the fact, as seen in the drawings, that the notochordal opening pierces the centrum precisely as it does in the later vertebræ - that is, between the pleurocentra and hypocentrum. If all three elements are coössified in the atlas, then it would lend support to the views held by some inorphologists, of. whom Broili has given the latest exposition, that the vertebræ of the amniota are composed of the combined hypocentrum, pleurocentra, and neurocentra.

The second vertebra of the series, which we may call the axis, because of its slight modifications in structure, has a smaller hypocentrum, as I have described, without parapophysial facets. The diapophyses are short and narrow at their extremity. The spine is much broader below than are the succeeding ones and pointed above, where it comes in contact at its extreme tip with the extreme front end of the carapace. On either side of the thinned anterior expansion of the spine below there is a slight depression, in which is lodged the slender flattened neuropophysis of the atlas.

\section{SAORUM}

(Plate 9)

As is well known, the reptiles and higher vertebrates, wherever they possess a sacrum, have invariably, or almost invariably, two or more 


\section{4 s. W. WILLISTON-NEW GENERA OF PERMIAN VERTEBRATES}

vertebræ composing it. And this is one of the characters which have been urged as indications of direct genetic relationship between the microsaurs, in which two sacral vertebræ are known to occur in some forms at least, and the reptiles. Hitherto, not only among recent, but also among extinct, amphibians, excluding the Microsauria, but one sacral vertebra has been known to occur, though I find certain references to sacra with two vertebræ among the older writers on the stegocephs. In Cacops we have two well developed pairs of sacral ribs broadly attached to the ilia. Of these, the first pair is a little larger and stouter than the second, though differing otherwise but slightly. The stout vertebral ends have two articulations, with a small non-articular surface between them, the upper and larger one attached firmly to the neurocentrum, the lower to the upper border of the hypocentrum, which again presents a parapophysial protuberance for its union. The somewhat crushed condition of the arches of the sacral vertebræ, as they were found lying in the pelvis, prevents the determination with certainty of the relations of the neurocentra to the hypocentra, but I suspect that they articulate on the sides with the ribs only and not with the hypocentrum. Beyond the articular head the stout shaft of the ribs is constricted for a short distance into an oval form, and then suddenly expands into the large flat or outwardly concave portion for union with the ilium. This thinned expansion of the first rib has an emargination on the upper posterior border, in which fits loosely the lower anterior border of the second rib, the two forming an elongated, nearly plane surface, which extends the whole length of the lower part of the ilium in its greatest width nearly opposite the upper part of the acetabulum. The first sacral hypocentrum is rather larger than the preceding one, with a parapophysial facet at each side for the rib. The second hypocentrum, of nearly equal size, has also a like facet. for the rib on each side. The neurocentra of these two vertebræ are in part missing, apparently due to some accident before fossilization.

TAIL

The tail was preserved complete, but the flattened end was slightly disclocated, doubtless due to its thin, compressed form. The small bones of the neural side of the first six, or pygal, vertebræ were so small and so confused in the matrix that not much could be made of them. The six pygal hypocentra were found attached in a continuous series. There is a slight, very slight, possibility than an additional one may have been lost in the matrix at the place where the dislocation occurred, but I think not. The tail could not have been more than a fourth of an inch longer or shorter than is shown in the restoration and plate. The first six, or 
pygal, hypocentra decrease rapidly in length. With the fifth is a short, rudimentary rib, a mere pointed tubercle, and several similar ribs were found loose in the matrix.

Beginning with the seventh, or possibly the eighth, caudal there is a continuous series of fourteen or fifteen with chevrons, some of them, as shown in the drawings, with the neural arches attached. It required a critical examination with a lens to distinguish the very small pleurocentra of the posterior ones; that I did distinguish them I am quite certain. The hypocentra are angular; the lower posterior part extended into stout chevrons, which were perforated near their base for the hæmal canal. The distal part of the tail was thin and high, possibly used as a rudder-like organ in life.

\section{$\boldsymbol{R I B B}$}

(Plate 12, figure 8)

Many of the ribs have been removed from their encrusting matrix with but little or no injury; some of the posterior ones, because of their extreme delicacy, could not be worked out completely. The first eight pairs have broadly expanded proximal extremities, with a distinct separation, save of the first pair, of the rounded and thickened capitulum from the more elongated and thinner tubercle. The upper border is nearly straight or gently convex on the proximal portion, convex beyond; for the three distal fourths or more the shaft is slender, gently flattened, oval in crosssection, and is curved downward. Beginning with the ninth rib, the proximal expansion is much less, and there is no distinction into capitular and tubercular articulations; the shaft is more slender. The ribs increase gradually in length to the ninth and probably to the tenth. Beyond this they decrease more rapidly in length. In the last two pairs, at least, they are reduced to tuberculiform rudiments, ending pointedly, and are apparently coösified with the diapophysis.

From the tenth to the eighteenth only the proximal parts were worked out-that is, their precise lengths could not be determined.

\section{SIGNIFICANOE OF HYPOCENTRA AND PLEUROOENTRA}

Two views have been and yet are held by morphologists as to the morphological significance of the pleurocentra and hypocentra of the rhachitomous amphibians. The first, that of Cope and Baur, ${ }^{7}$ is that in the evolution of the higher vertebrates the pleurocentra progressively devel. oped to form the centrum, while the hypocentrum as progressively

\footnotetext{
TCope: Transactions of the American Philosophlcal Soclety, vol. zvi, p. 243. Baur: Blologis. Centralbl., vol. $\nabla 1,1886$, p. 12 ; American Naturallst, 1897, p. 975.
} 


\section{S. W. WILLISTON-NEW GENERA OF PERMIAN VERTEBRATES}

diminished, leaving a vestige only in the intercentrum of the modern Sphenodon and other reptiles, and possibly certain mammals. On the other hand, Cope, at least, believed that the pleurocentra disappeared in the holospondylous and modern amphibians, the hypocentrum persisting as the centrum.

The other view, that of various authors, notably Gaudry, Goette, Gadow, Jaekel, and Broili, is that the pleurocentra and hypocentrum fuse to form the centrum of all the higher vertebrates.

Unfortunately, both of these views must remain as hypotheses until, it is hoped, some fortunate discovery of intermediate forms may confirm or reject one or the other or both. In favor of the second view, which has been well presented by Broili, ${ }^{8}$ it is scen (plate 12, figure 5) that the pleurocentra articulate with each other in the middle, inclosing below and between them and the hypocentrum a notochordal perforation, quite analogous, perhaps homologous, with the central perforation in all primitive holospondylous vertebræ. With a close fusion of the four elements of the vertebræ and obliteration of the sutures a rhachitomous vertebra would be practically indistinguishable from a notochordal vertebra of the early reptiles. Moreover, the presence of distinct elements in the primitive cartilaginous vertebræ of the chick, in addition to the arch, assumed to be pleurocentra and hypocentra, would suggest their persistence closely fused in the ossified centrum.

This explanation would seem to be the most reasonable of any, especially if we had to deal with the modern amniota alone. Unfortunately, there are objections, ones recognized by Cope and Baur, which complicate matters. In the first place, this theory would necessitate the recognition of a morphological distinction between the intercentra as originally so called by Cope, and as found in the living Sphenodon, and the primitive hypocentra. It is a well known fact that intercentra are far more prevalent among the old forms than the modern ones; that practically all reptiles with notochordal perforations possessed them, while only restiges are found among modern reptiles save Sphenodon, leaving for the present the cherrons out of account. In the modern crocodilia alone has every vestige of them disappeared back of the atlas, while the lizards possess them throughout the neck, and turtles have at least one or two back of the atlas. If they are morphologically distinct elements, what explanation can be given for their origin and wide prevalence among the early reptiles and their gradual disappearance in the modern forms? They are known only in the amninta. Neither of the

\footnotetext{
- Monatschr. (1. Dentschen Geologisli. Genselisch., ix, 1008, 1), 236.
} 
views as to the fate of the pleurocentra will militate against the commonly accepted theory of the structure of the atlas, where the united pleurocentra do not fuse with the hypocentrum, but remain distinct as the odontoid process of the axis. But we have in such forms as Dimetro$d o n$, as well as all other Permian reptiles, to say nothing of the modern lizards, a very large element, often larger than the atlantal hypocentrum itself, intercalated between the atlas and the body of the axis below. If it be an intercentrum purely, it has assumed enormous proportions, suggesting very forcibly the original size of the intercentra throughout the column. If it be a hypocentrum like that of the atlas, we are irresistibly driven to the conclusion that either the body of the axis is its pleurocentra, or else that the pleurocentra and neurocentra of an intercalating vertebra have disappeared between the axis and atlas, leaving only the large hypocentrum. And if this hypothesis be true, then a like explanation would be necessary to account for all the intercentra, which certainly are morphologically identical with the intercalating element in Dimetrodon. But such a theory is altogether too tenuous for me. It may be all very well to account for the ossifications between the centra in Sphenodon as new elements originating from one knows not what and call them intercentra or subcentra, as Jaekel has very superfluously renamed them, hut will some one give a reasonable explanation of the very large preaxial intercentrum in Dimetrodon and the other early reptiles, as well as the lizards, on this hypothesis?

Again, it is a remarkable fact, for which no reasonable explanation has ever been given save by Cope, that in all true amphibians, both ancient and modern, the chevrons are an integral, inseparable, exogenous part of the body of the vertebræ, while in all reptiles and higher vertebrates they are the intercentrum or part of it. In other words, they are in all rhachitomous and embolomerous amphibians a part of the hypocentrum, a prolongation of its lower part, perforated for the passage of vessels, immovably united, while in all amniota they are freely articulated between the vertebræ, or, as in some lacertilia, with the posterior part of the body itself. Free chevrons have never been discovered in true amphibians, and until they are we are compelled to assume that they are the hypocentra, and thus, under the second hypothesis, must be morphologically distinct from the cherrons of the amniota which are attached intercentrally.

It is a remarkable fact that intercentra have never been discovered in any amphibian, ancient or recent. In the Microsauria we have in some cases well developed vertebræ associated with a fully ossified skeleton, but so far no intercentra have been discovered in this group. so far as I am aware, nor free chevrons, save in Hylonomus. Again, the primitive rib 


\section{8}

S. W. WILLISTON-NEW GENERA OF PERMIAN VERTEBRATES

in the reptilia was articulated invariably with the intercentrum and neurocentrum, and never with the centrum exclusively. In the rhachitomous amphibia the articulation as seen in the present form was with hypocentrum and neurocentrum. Probably that was the invariable rule, for I know of no amphibian in which the capitulum of the rib articulated between the centra. This fact is suggestive, at least.

Yet, further, in the embolomerous forms it is the pleurocentra which become detached from the remainder of the vertebra to form an independent disk between the hypocentra, just as is the case in the atlas of the amniota.

I am fully conscious that the theory of the hypocentral origin of the centra of modern amphibians and the exclusively pleurocentral origin of the same of the amniota seems a bit improbable, though, of course, not impossible; I am not ready to receive it as a safe theory yet; I am still less ready to accept the theory of the independence of intercentra and hypocentra morphologically, as the other theory demands.

On a later page of this article $I$ give the description and figures of a remarkably amphibia-like reptile, in which the vertebral structure seems to be intermediate between the rhachitomous and the reptilian type. It is not decisive, but is very suggestive.

\section{PECTORAL GIRDLE AND EXTREMITY}

Scapula coracoid.--The scapula coracoid (plate 10, figure 1; plate 11, figure 1) is a relatively large bone, with no indications of sutural division into its supposed component parts. The blade is moderately expanded above, gently concave on its outer, convex on its inner, surface. Its upper border is a little convex longitudinally, its edges sharply truncate for cartilage. The posterior border is thickened to the beginning of the glenoid concavity; the corresponding anterior border is thinned.

The posterior border divides to include the supraglenoid fossa, perforated at its bottom by the supraglenoid foramen. The outer border continues downward, and by a gentle curve backward to terminate in the oval preglenoid facet, which looks downward, backward, and outward. The inner margin, the thicker, extends downward, inward, and backward, with an anterior curvature. In one specimen the end is angularly truncate, in all probability for a small metacoracoid that was not ossified. In the others it continues in a thin border back of the margin of the posterior glenoid facet. This latter facet is near the lower part of the bone, an elongate concave surface, with sharp margins posteriorly, and is opposed to the anterior facet already described. Betwreen these two facets and a little above them the glenoid foramen pierces the bone obliquely 
hackward to open on the inner surface a little hack of the border of the subscaptular losisi, in which the supracoracoid and the supraglenoid foramina both open. 'The lower antcrior part of the bone is thickened. with truncate edges, and is convex in outline. 'The upper end ol the (artilagious bordes continues hackward as an angular thickening, nearly on a level with the upper border of the preglenoid facet. The thickening extends as a ridge a short distance backward. In much probability this ridge limits the upper border of the epicoracoid, since in the immature specimen already spoken of a sutural line seems to run directly backward below the upper edge of the preglenoid facet, quite as in Varanosaurus. The lower edge of the preglenoid facet continues as a rounded border downward and forward part way to the lower margin of the bone. In the cavity thus formed at the lower end of the facet is the opening of the supracoracoid foramen. On the inner surface of the bone, near the middle, extending downward subparallel with the anterior border of the hone, is the anterior border of the subscapular fossa. In its middle part the free border overhangs a deep fossa looking backward, at the upper end of which opens the supraglenoid foramen; at the lower end is the opening of the supracoracoid foramen. Back of this margin the bone is convex, and is pierced by the inner opening of the glenoid foramen.

Cleithrum.-The cleithrum, found in position on either side, is remarkable for its large size. Its lower part is a long rod closely attached to the anterior margin of the scapula as far as the angular thickening $T$ have described; it is overlapped through nearly its whole extent by the upper part of the clavicle. The upper part of the cleithrum is broadly dilated and thin, covering the upper border of the scapula to its hind angle and arched inward. Its borders are very thin, convex above, concave below; the posterior thin margin is nearly straight. The bone above forms a sort of roof, convex outwardly, concave inwardly.

Clavicles.-The clavicles are small, somewhat spoonshaped, with curved handle. The upper, slender part is closely applied to the outer, anterior side of the lower. rodlike part of the cleithrum, reaching nearly to the dilated portion. The lower end, curved inward and a little backward, is dilated with thin margins, concave on the inner side where it articulates with the interclavicle, convex on the exterior or lower surface. It underlaps the interclavicle and partly covers the lower anterior border of the epicoracoid.

Interclavicle.-The interclavicle is a small, thin bone dilated and thinned in front where it overlies the ends of the clavicles, which touch in the middle. The posterior extension or "stem" is short, not as long as the expanded part. 
Humerus (plate 11, figures $2-5$ ).-The humerus is of the usual temnospondyl form, differing from that of Eryops and Trernatops especially in the absence of the ectepicondylar process, so conspicuous in the former and in Euchirosaurus. It is broadly expanded at either extremity in planes nearly at right angles with each other, and has a rather slender shaft in the middle. The lateral or radial process is very stout; the medial or ulnar process is indicated by a slight ridge or elevation just below and in front of the inner extremity of the proximal articular surface. The digital fossa on the inner side is rather shallow and broad. The short shaft is subcylindrical in cross-section, with a sharp ridge running from the outer side of the lateral process to terminate in the supinator ridge. The capitular surface for the radius is subhemispherical in shape, looking mainly forward. The trochlear surface for the ulna is small. The inner, condylar border is moderately dilated and relatively thin; the ectepicondylar or supinator border thick. There is no indication whatever of the ectepicondylar process below the lateral process on the outer side.

Humeri of allied forms.-Among the early land vertebrates no part of the skeleton is more characteristic than the humerus. As a rule, the humeri of the amphibia and reptiles resemble each other markedly-rather stout and short bones, with the extremities greatly expanded and their planes divergent from each other in an angle of from 60 to 90 degrees. Though usually thickset and short, in some of the reptiles it is as slender as that of existing lizards, an example of which is seen in the humerus of Pleuristion, a small cotylosaurian reptile-a little smaller than the existing Sphenodon. Climbing reptiles have slender humeri, fossorial and aquatic reptiles thickset and short humeri, though in some amphibious forms, such as the crocodiles, it is rather slender. In strictly terrestrial, cursorial reptiles it is never short and stout, from which it may be inferred that the amphibians and reptiles from Texas with such thickset humeri are either fossorial or aquatic. But it is an inference only, since there may be other causes to account for the robustness, of which we are not yet aware. One conclusion is, however, justifiable: animals with such humeri as are shown in plate 15, figures 4 and 5 , were certainly not quick running in habit!

As a very general rule, the humeri of amphibians and reptiles may be distinguished by the absence of an epicondylar foramen in the former; its frequent presence in the latter. Among living reptiles the crocodilia have neither; Sphenodon has both ectepicondylar and entepicondylar foramina. Lizards frequently have an ectepicondylar foramen or groove; even the mosasaurs possess such a groove, though no record of 
it has hitherto been published. The Chelonia have, like the lizards, an ectepicondylar foramen or groove. Among the Amphibia an entepicondylar foramen was described by Cope in Acheloma, but an examination of the type specimen shows that while apparently present in one humerus, in its mate there is no indication of it, and the opening in the one may safely be ascribed to some accidental injury or malformation, especially so since its position and form are aberrant. So, also, Euchirosaurus has been restored with such a foramen, or rather with an ectepicondylar opening, but quite incorrectly so. The euchirosaurian humerus is of the strictly Eryops type, and like Eryops it does not have an epicondylar foramen. There are but two known amphibians, ancient or modern, with an epicondylar foramen, Diplocaulus and Cochleosaurus.

In the collections of the University of Chicago there are well preserved humeri of not less than ten genera of Texas amphibians. In addition to these I have examined the humeri of Acheloma and Dissorophus, and Broili and Case have figured the humerus of Aspidosaurus. Of four Permian genera the humerus is unknown-Zatrachys, Anisodexis, Cardiacephalus, and Cricotillus. The last-named genus is very doubtfully distinct from Crossotelos. Anisodexis is a large form, clearly allied to Eryops, and doubtless with a humerus similar to that of Eryops. Cardiacephalus is a very small amphibian, altogether too small to belong with any of the femora figured in plate 15. Of the remainder Cricotus may possibly be represented among the unidentified forms, but probably not, since nearly all the material in the Chicago collections are from the upper horizons, all of the humeri herewith figured, an horizon in which neither Cricotus nor Zatrachys occurs. One other genus may be mentioned, Lysorophus, of which evidence of limbs is found among the material in the collection, but the bones are small, almost minute. It thus is almost certain that we have evidence of at least fifteen genera of Permian amphibians from Oklahoma and Texas. I know of none from the reputed Permian of Illinois save Diplocaulus and Cricotus.

Of the humeri shown in plate 15 two certainly do not belong among the temnospondyles, those of Crossotelos (figures 2 and 3) and Diplocaulus (figure 7). Of Crossotelos I have seen a half dozen or more humeri from the Orlando bone-bed, always associated with vertebræ of the typical form and never with other forms. Its character was not recognized when first discovered, and the ends are unfortunately reversed in the drawings. It is a simple bone, moderately expanded at the extremities, with a rather deep concavity longitudinally behind, and with but a small lateral rugositv. All the specimens found show an incomplete chondral ossification. The form was doubtless more or less aquatic, Diplocaulus. 
the only known amphibian, save Cochleosaurus, with an epicondylar foramen, has been referred to the Microsauria or Lepospondyli by Cope, Broili, and Jaekel, as also by myself provisionally, but, as I pointed out in a recent paper, ${ }^{10}$ the mode of attachment of the ribs is quite unlike that of the typical microsaurs and like that of the modern salamanders. Doctor Moodie has, because of this character, erected the new order of Diplocaulia for the genus, and I believe the name is valid, though the rank of the group is open to dispute. Crossotelos Case, a form with holospondylous vertebræ, found associated with Diplocaulus at Orlando, has distinctly double-headed ribs, with the capitulum attached to a facet just back of the front margin of the vertebral centrum, the tubercle to the extremtiy of a short diapophysis. True microsaurs have singleheaded ribs attached intercentrally, with the chevrons presumably attached also as in reptiles. In both Diplocaulus and Crossotelos the chevrons are quite like those of the true amphibians, exogenous processes from the middle of the centrum. But I am quite confident that at least two distinct groups have been associated among what are called Microsauria, and that one of them, with single-headed, intercentral ribs and intercentral chevrons, must be dissociated into a group more nearly allied, possibly identical, with the reptilia in a wide sense, while the other will remain among the amphibia. As I am not able at the present time to decide which of these groups includes the type form of the order, it is premature to attempt the solution of the problem by giving new names. This thing, however, may be said with assurance, neither Diplocaulus nor Crossotelos can be united with such forms as Eosauravus copei Will. (nom. nov., Isodectes punctulatus Cope in part, Isodectes punctulatus Moodie), or Sauravus costei Thevenin. Crossotelos has numerous slender ventral ribs, very much like those of Labidosaurus and Captorhinus (Pariotichus), of which I have found abundant evidence in new material from Texas.

The humerus of Trimerorhachis (plate 15, figure 6) departs markedly from the ordinary temnospondyle type, as do also the femora, in which the adductor ridge is represented by a mere line on the ventral side of the femur quite as in the reptiles, and unlike all other known Texas amphibians. It is also remarkable for the small size of the lateral process, which is separated from the head by a considerable free space. This process is divided for the attachment of the several muscles into two rugosities opposite each other on the front and hinder surfaces. The median process, usually feebly indicated in the amphibians, is clearly

- Brolli: Paleontographica, lil, p. 15, fig. $3 a$.

10 Transactions of the Kangas Academy of Aclence, vol, xxil, p. 122. 
seen in a small but prominent hooklike process on the inner posterior side near the head. The proximal articular surface is, it is seen, quite at the extremity, suggesting a limited range of motion as compared with other forms, and it is also the case with articular surfaces for the radius and ulna. Here, as in other cases, the absence of distinct condylar surfaces may be of generic value or merely ontogenetic. While, as is well known, many amphibians, both extinct and living, do not have a complete chondral ossification, leaving the articular surfaces throughout life composed of cartilage, yet it is also quite possible that such a condition found in fossilized bones may be merely indicative of juvenility. In Trimerorhachis, however, it seems certain that the character is one of maturity, since more than a dozen humeri and a score or two of other limb bones in the collection all present the same unossified condition. From all of which facts I think the conclusion is obvious that Trimerorhachis was an aquatic form, notwithstanding the slenderness of the humeri, which simply is an evidence of a short tail and limb propelling habits.

Three other humeri figured in plate 15 are certainly of new genera. Two of them, figures 4 and 5, are of the usual temnospondylous type, but a third (figure 1) may represent a new type of amphibian from Texas. This humerus, it is seen, is an unusually slender bone, with its articulations well developed. The lateral process is small and the condyles are feebly developed. The bone, as preserved, shows but a slight twisting of its proximal from the distal plane, which may be in part due to the conditions of fossilization, though I think not. The genus when it is better known will, I believe, be found to be of a slender terrestrial type.

The humerus shown in figures $4 a, b$, and $c$ is remarkable for its massiveness and shortness, in both respects excelling any other which I know. Here also the chondral ossification is deficient, the articular condyles, both proximal and distal, being roughened, more or less concave surfaces, doubtless thickly covered by cartilage in life. The humerus shown in figure 5 was found associated with that illustrated in figure 4 . It is more of the Dissorophus type, though distinctly different, as were also its femora found associated with it. It also has an imperfect chondral ossification.

All of the humeri so far described lack the peculiar process just above and to the outer side of the capitellar convexity, so characteristic of Eryops, Euchirosaurus, and apparently also Trematops. It may be called the ectepicondylar process, and seems to be homologous with a similar process found in the Pelycosauria, but hitherto unknown in the Cotylosauria. 


\section{4 s. W. WILLISTON-NEW GENERA OF PERMIAN VERTEBRATES}

In a future communication I shall give a similar comparative illustration of the humeri of the reptiles, of which there are in the collections of the University of Chicago 12 distinct forms, representing as many genera.

Radius (plate 14, figures $7-9$ ).-The radius has a very slender shaft in the middle, and is broadly and thickly expanded at either end. The posterior border is nearly straight, the anterior deeply concave, the two lateral borders nearly symmetrically and deeply concave in outline, the extremities of nearly equal width and nearly transversely truncate. The proximal end has a groove on the posterior side thinning the inner articular surface.

Ulna (plate 14, figure 10). - The ulna is a remarkably slender bone in comparison with the radius-slender in comparison with the bone in other genera of Permian air-breathers. It has a slender and curved shaft on the distal three-fifths, the distal extremity only a little widened, with its greater diameter at right angles to the greater diameter of the proximal end. The olecranon is very slightly produced, and the articular surface for the humerus is oblique to both axes of the bones; the inner side of the proximal end is flattened.

Two bones of the proximal row of carpals with several phalanges were found close to the bones of the left forearm. They are relatively small. Their characters may be seen in the figures (plate 12, figure 3 ).

\section{PELTIO GIRDLE AND EXTREMITY}

Pelvis.-The pelvis (plate 12, figure 4; plate 13, figure 1) is very strong and stout, the two halves meeting in a very firm symphysis, which forms an obtuse ventral ridge most protuberant in the middle below the acetabulum. The pelvic cavity is deep and spoutlike, nearly semicircular in transverse outline, with the lateral margins anteriorly and posteriorly slightly flaring. The anterior border is emarginate in the middle, the sides convex in outline, with a notch. The posterior margin is slightly narrower than the anterior, and has a deeper emargination in the middle line, the sides somewhat thinner, with convex borders to the outer, somewhat angular margin. The posterior margin of each innominate is concave from the upper angle of the ilium, with a pronounced angular projection in the imiddle of the concavity at the junction of the ilium and ischium; this border is rather thin throughout. The front border is likewise concave throughout from the upper angle of the ilium, with a slight convexity below the middle at the place of junction between the ilium and pubis. This border is much thicker than the posterior, and flares outwardly below. The acetabulum is deep and large, with its greatest 
concavity below its middle. It has a distinct and rather protuberant rim, save at the upper posterior part. Its upper border on the ilium is marked by a small but distinct process overhanging the concavity. The lower margin on the ischium is very prominent, forming an angular projection to the full width of the bone, while the stout expansion of the pubis in front limits the deepest concavity of the acetabulum. The shape of the acetabulum would indicate that the chief pressure of the femur was directed nearly horizontally and a little backward. The lower rim is nearly horizontal, deeply concave antero-posteriorly, overhanging the almost horizontal outer surface below. The pubes flare outward on each side in front from a subangular line, running downward and inward through the inner orifice of the obturator foramen to either side of the median emargination of the front border. The triangular surface either side thus limited looks at an angle of about 45 degrees upward from the horizontal position of the pelvis and slightly inward, and is gently convex from side to side. The under surface on the sides of the conjoined pelvis is nearly horizontal laterally, descending in the middle into a broad obtuse ridge, broadest and deepest a little in front of the middle. In front the downward curvature of the pubes leaves a concavity, at the bottom of which is the external opening of the obturator foramen, very near the middle of the pubis antero-posteriorly, and opposite the greatest protuberance of the pubic margin, not far from the border of the acetabulum. The front border of the pubes is roughened for cartilage. The sutures separating the elements are very clearly shown in the present specimen. Those between the ilium and ischium and pubes begin on the margins near the middle of the convexities described and run downward to meet a little below the middle of the acetabulum, that for the ischium being a little longer than the one for the pubis. The puboischiadic suture runs directly inward through the deepest part of the lower margin of the acetabular rim, the length of the ischia below being about a fifth greater than that of the pubes. The depth of the lower pelvic border is due solely to the breadth of the symphysis, the upper surface of the pelvis in the middle showing no corresponding concavity.

Femur (plate 13, figures 2-5).- The femur is remarkable among temnospondyles for its slenderness and the great development of the adductor crest. The proximal articular surface has its transverse diameter but little greater than the antero-posterior one, narrower on the outer side, more convex on the inner, where the articular surface extends more on the ventral side. The digital fossa is small and shallow. The adductor crest arises near the upper part of the bone, is directed outward for a short distance, and then is nearly straight to its distal end near the 


\section{S. W. WILLISTON-NEW GENERA OF PERMIAN VERTEBRATES}

lower fifth of the bone, and near the middle of the popliteal surface. The shaft of the bone for about the middle two-fifths is very slender, almost cylindrical, save for the crest behind, and is straight. The distal expansion of the bone begins a little above the lower fifth and is a little greater than the proximal one. The lateral linear concavities of the bone on the two sides are nearly symmetrical. The distal articular surface of the bone has sharp borders, indicating a considerable amount of cartilage. The end is much broader transversely than from before backward. The transverse tibial surface looks downward and a little backward and inward. The fibular surface is a little longer from side to side and looks markedly outward, backward, and downward. Its width in the inner side is more than one-half of the whole width of the extremity, with narrow extensions both in front and behind. The fibular condylar projection is much thinner and less extensive than the tibial. The extensor groove in front of the distal end is broad and moderately deep, limited on the outer side by a high and rather sharp ridge. On the back side a less prominent, more obtuse ridge opposite the dorsal ridge, and connected with the distal end of the adductor crest, separates a shallow concavity on the inner side from a narrower and deeper one on the outer side.

Tibia (plate 14, figures 1-4).-The tibia is more than three-fourths the length of the femur. Its upper extremity, as usual, is broadly expanded and massive, the lower less expanded and more cylindrical. The upper surface for articulation in the normal position of the bone is broad from side to side and about two-thirds as wide from before back, thicker on the outer than on the inner side, with an emargination on the outer anterior side, the anterior border internally convex, the posterior border nearly straight. The surface is gently convex from side to side, nearly flat antero-pasteriorly, and looks on the whole upward and a little backward. The distal articular surface is suboval, its longer diameter running from behind outwardly and anteriorly, with the internal border convex, the outer posterior border more nearly straight or gently convex. The shaft is slender in its middle, broader in section from before backward, and is flattened on the inner side. The inner border of the bone is deeply concave, the outer almost straight, save at the lower end. The posterior surface of the bone is flattened on the upper expansion, bounded inwardly by a sharp sinuous crest, which becomes confluent with the convexity of the distal extremity.

Fibula (plate 14, figures 5 and 6).-The fibula is shorter than the tibia, flattened upon its posterior inner surface, and convex from side to side on the opposite. The outer thinner margin is nearly straight to the lower fourth, where it curves inward. The inner border is deeply 
concave, more so on the lower half. The lower extremity is more expanded than the upper, and is also thicker, strongly convex in front, and somewhat concave on the posterior surface. In the vertical position of the bone the upper articular surface is nearly horizontal, while the lower is directed at an angle of about 20 degrees inwardly.

Associated with the leg bones were found a number of tarsal and phalangeal bones, figures of which will be found in plate 12, figures 1 and 2. Their precise position can not be determined, more than that two of the tarsals belong in the proximal row and three of the toe bones are metatarsals.

\section{Taxonomy}

\section{DISSOROPHUS MULTIOINOTUS}

From West Coffee Creek, in Baylor County, I was so fortunate as to find a considerable part of a skeleton of Dissorophus multicinctus, which adds not a little to our knowledge of this genus. The parts preserved are the nearly complete skull, with the palatal region imperfect, the nearly complete carapace, with several vertebræ attached, the nearly complete pectoral girdle, humeri, parts of the radius and ulna, the imperfect pelvis, a femur, parts of the tibiæ, and several tarsal bones. They will be figured and described soon by the writer. The skeleton agrees in its essential characters closely with Cacops, but is generically distinct in the much greater development of the carapace, with its fused anterior dermal bones, armadillo-like, and in the much greater stoutness of the appendicular skeleton. From this specimen and the material of Cacops may be given the following family and generic characters. In the family characters I italicize those based exclusively upon Cacops.

\section{DISBOROPHIDA-FAMILY NEW}

General characteristics.-Skull with the otic notch completely enclosed to form a large ear cavity. Palate with but two large teeth on each side, one at the anterior inner margin of the nares, the other at the posterior margin; mandibular and maxillary teeth of nearly equal size. Parasphenoid reduced. Twenty-one presacral vertebre; two sacral vertebre; tail short. A dorsal carapace, composed of lateral expansions of the spines of the vertebræ, with overlying intercalated dermal plates. Cleithrum very large and expanded above. Clavicles small, without exterior pittings. Interclavicle smooth on the dermal surface, small, with a short posterior process. Humerus without ectepicondylar process. Femur with strong adductor crest. 


\section{8 s. W. WIJLISTON-NEW GENERA OF PERMIAN VERTEBRATES}

Genus Dissorophus Cope.-Dermal carapace extending the full width of the body, with a broad and elongated shield in front covering several vertebræ. Cleithrum less expanded and thicker. Scapula much expanded antero-posteriorly below. D. multicinctus (articulatus) Cope.

Genus Cacops Williston.-Dermal carapace but little wider than the vertebræ, narrowed in front and not fused into an anterior shield. Cleithrum thin and more expanded. Scapula less expanded below, the interclavicles and clavicles more slender. C. aspidephorus Will.

\section{TREMATOPSIDAD-FAMILY NEW}

It is very evident that the characters of Trematops as given by $\mathrm{me}^{11}$ are of more than generic importance. The genus represents a distinct family, which may be defined as follows:

A median foramen back of premaxillæ; large antorbital vacuities. Otic notch wholly enclosed by bone, the opening small and extending far forward. Palate with two pairs of large teeth back of the nares and a single one on each vomer. No parasphenoid. Ribs short, the anterior ones expanded distally. Twenty-two or twenty-three presacral vertebræ; a single sacral; tail short. No dermal armor or carapace. Cleithrum unknown. Clavicles and interclavicle small, without dermal pittings. Humerus with ectepicondylar process. T. milleri Will.

\section{RESTORATION}

\section{(Plate 17)}

The figures of Cacops aspidephorus given in the following plates and the mounted skeleton of plate 17 are nearly all from a single specimen, found with all of its parts intact and closely related in the matrix, lying in a prone condition. It was lying near the right side of one of the blocks of clay, taken up with the aid of bandages, and in separating the blocks some fragments of the right limbs were probably lost; the remainder probably are yet lying in the adjacent block, but the time required to work out each of these separate blocks, with their numerous skeletons and parts of skeletons, has rendered it inadvisable to wait till the whole material has been prepared before publishing, especially as but very little new information is to be gained. Inasmuch as the other skeletons exhumed are of a slightly larger or smaller size, their bones have not been used to replace the tibia and fibula, radius and ulna, and feet of the right side, which have been modeled in plaster from the left side. Numerous

11 Journal of Geology, July-August, 1909, p. 389. 
foot bones have been found dissociated, and probably a large part of the material must he worked over before the feet are found in all their natural articulations, inasmuch as it required the working out of six or seven feet and four or five hands of Varanosaurus from the same blocks before every detail of the structure of the extremities of that genus was determined. The foot bones thus have been arranged in the mounted skeleton after those of Trematops and Eryops, and it is quite certain there can not be much error. Nevertheless, it is expected that even these details will be determined in the course of a year or two. As is stated in the description, the precise lengths of the tenth to the eighteenth ribs could not be determined from the single specimen, as also the precise structure of the arches of three or four of the proximal caudal vertebræ. These have been restored, and it is not at all probable that the real bones when found will make any discernible difference in the mounted skeleton.

Everything else, to the smallest details of the mounted skeleton, is bone; the only plaster used was that necessary to cement the pieces together when broken in preparation. Furthermore, the posture of the skeleton is almost exactly that of the fossil as it was preserved in the matrix. Upon the whole I doubt whether there is another mounted skeleton of an extinct reptile or amphibian about which there is so little of error or with so little restoration as the present one.

The creature as mounted presents an almost absurd appearance, with its large head and pectoral region, absence of neck, and short tail. It is very certain that it possessed no other dermal ossifications than those of the median dorsal carapace, and it would seem almost as certain that the creature was aquatic or largely amphibious in its habits. Almost froglike in appearance, it doubtless had more or less froglike habits. What the significance of the dermal carapace was $I$ am at a loss to suggest. That it could have been of protection to the creature seems more than doubtful, whatever may have been its use in Dissorophus, where it covered the whole dorsal region. But this coincidence is remarkable: With an external turtle-like ear opening, it had also the beginning of a turtlelike carapace. And this parallelism is also seen in Diadectes, a reptile with dorsal dermal plates and turtle-like ears. It is quite possible that the toes may have been a trifle longer than they are shown in the mounted skeleton-that I hope to determine later, but it is not probable, judging from the considerable number of phalangeal bones that have been found with the skeletons. That the animal was a swimmer I do not doubt, and in all probability the feet were webbed-they were certainly not clawed. Whatever may have been the habits of the creature, it, with its nearly 
related Dissorophus, must be classed among the oddities of vertebrate paleontology.

\section{Desmospondylus anomalus-Genus and Species new}

(Plate 16)

The specimens representing a peculiar type of reptiles, which I am constrained to regard as new, were discovered by Mr. Paul Miller within a few rods of our camp on West Coffee Creek, Baylor County, Texas, from about the middle portion of the Permian beds. A series of small vertebræ was found partly protruding from the clay, about 6 inches below another specimen of larger size, which was recognized as a species of Trimerorhachis. Many of the fragments of both specimens had been intermingled in the wash, and several hours were spent in carefully removing the clay containing them and washing out the fragments in the near-by Coffee Creek. The bones, fortunately, were firm and hard, and entirely free from matrix, though broken into many fragments. A study of this loose material discloses a large part of a skeleton of Trimerorhachis and numerous fragments belonging to the present species. The mass of clay taken up with bandages included the series of about a dozen vertebræ, with two humeri, right and left; two ilia, also right and left; a femur and two tibix, right and left, with a portion of a fibula and several phalanges. In addition a part of a large interclavicle was also found in the clay matrix. In the wash were found another humerus, a femur, two ilia, and a radius, and probably fragments of ulnæ and tibiæ, all of a slightly larger size, though otherwise agreeing closely with the corresponding bones found in position, or nearly in position, in the matrix. Whether this second specimen had been originally associated with the other in the same horizon, whether it was associated with the Trimerorhachis, or whether indeed it came from still a higher horizon, it is impossible to say.

In addition to this material belonging to one species, another femur nearly twice the size and more slender in form, though otherwise quite similar, was found a few weeks later associated with the remains of Cacops, described in the present paper. Its horizon was probably nearly that of the present species. From the famous bone-bed of Danville, Illinois, Mr. Gurley obtained, a good many years ago, a large and well ossified humerus which has long been a puzzle. Case figured this specimen, without assigning it to any known genus, in his paper on the Illinois specimens in the Journal of Geology, volume VIII, plate III, figures $4 a$, $4 b$. It has long been considered an amphibian, notwithstanding the 
presence of an entepicondylar foramen. It unquestionably belongs in the present genus.

The University of Chicago collection of Permian vertebrates from 'Texas and Oklahoma now includes representatives of at least 26 genera, all of which I know more or less well. Five or six of the genera described from Texas and Oklahoma, some of them on fragmentary material, I have so far not identified, though I have seen the types of several. 'They are Cricotillus Case, of doubtful validity; Seymouria and Cardia'ephlualus Broili; Isodectes, Pantylus, and Anisodexis Cope. It is, hence, possible that our genus may be identical with some one of these, but the probability is so slight that I have no hesitation in giving the new generic and specific name to the present specimens.

The vertebræ, of which there are 20 or more centra and fragmentary arches, in addition to the connected series of 7 or 8, present some extraordinary characters-characters which are very suggestive of amphibian affinities, annectant between the rhachitomous and holospondylous types. The centra, coming all of them apparently from the posterior dorsal region and the tail, are short, almost disklike, deeply concave, with a small perforating foramen. The arches are entirely free; the sutural surface for their attachment is extensive, situated on the anterior threefourths of the centrum and extending downward on the front margin to below the middle. Back of this sutural surface there is a similar beveled surface extending about one-fourth of the length of the centrum, which also reaches down on the posterior side to the middle of the centrum. The arches are very low, with a rudimentary spine only, resembling the arches of Labidosaurus or Captorhinus. The zygopophyses are very large and broad, with their surfaces nearly horizontal. Below and back of the anterior zygapophyses there is, on either side, a distinct diapophysis, on the more anterior vertebræ standing out prominently, on the posterior ones a mere rugosity. Lying by the sides of these processes were a number of small ribs, which seem to have been single-headed, inasmuch as no double-headed ribs were found in the matrix. However, as Labidosaurus has quite this form of diapophyses posteriorly with double-headed ribs, it is not impossible that such was the character of the ribs in this genus.

The anterior border of the pedicel, beginning low down, projects forward, so that if two vertebræ were closely applied the arch would rest on two centra, though chiefly on the posterior one, and, so far as I can determine from careful measurements, this would be the case with the zygapophyses closely interlocked.

That this was not the condition ordinarily, however, is rendered certain by the presence of extraordinarily large intercentra found in position 
between several of the centra. Relatively, as compared with the centra, these intercentra are the largest known in any vertebrate, suggesting impressively the lower half of the pleurocentra of Cricotus. When in position they reach upward to the middle of the centrum, and almost or quite touch the extremities of the arch. (See plate 10, figure 3, and plate 16, figures 8-12.) If the ribs were double-headed the capitulum must have articulated with the upper ends of the intercentra. These intercentra are narrower above, so that there is left a distinct free space between the upper parts of the adjacent centra in the horizontal straight position of the column. When curved upward, however, the arches would fill the interstice between the contiguous vertebræ, leaving a wedge-shaped space below filled with the intercentrum. Some of the centra preserved are hardly more than half the diameter of the largest. They are evidently caudal vertebræ, though no indications of chevrons have been discovered. Others are even more disklike than the ones figured, resembling so closely various centra attributed to Cricotus from the Illinois deposits, that it is probable that they really belong in this genus and are centra, rather than to Cricotus. especially so as they agree in size with the femur mentioned above.

Not only are the vertebræ so curiously intermediate between the ordinary reptilian type and the embolomerous type, but the limb bones, both humeri and femora, were referred unhesitatingly to the amphibians before the vertebræ were recognized. The humerus (plate 16, figure 1) is extraordinarily stout and rugose for its length. Immediately below the lateral process there is a stout process, hitherto characteristic of certain temnospondylous amphibians, which I have called the ectepicondylar process, most characteristically seen in Eryops and Euchirosaurus. No such process is known in any Permian reptile, certainly in no Cotylosaurian. Furthermore, the median process is developed into a stout protuberance, quite as in Eryops. On the other hand, there is an entepicondylar foramen, remarkable for its large size, known only among amphibians in Diplocaulus and Cochleosaurus, wholly unrelated forms.

The femur (plate 16, figures 4,5 ) also is remarkably amphibian in character in the extraordinary development of the adductor crest, a character known in no other Permian reptile. The digital fossa is extraordinary for its extent and depth, reaching nearly to the middle of the hone. The bones identified as tibia and radius (the former was found close to the femur and ilium, the latter in the wash) present no peculiar characters, though remarkably stout and robust (figures 2,3 ).

Among the material in the wash are fragments of a small skull mingled with Trimerorhachis skull material, but there is too much doubt of their 
reptilian character to make it worth while describing them until further evidence of their identity is forthcoming.

That the present genus is not a pelycosaurian is, of course, evident; its relationships with the cotylosaurians are more apparent. Nevertheless, the great differences in the structure of both vertebræ and limb bones from anything known among either the diadectid or pariotichid types render the exact position of the genus very doubtful. Possibly, as I have said, it may eventually turn out to be congeneric with some one of the few forms in which the vertebræ and limb bones are yet unknown, especially Pantylus.

\section{Explanation of Plates}

All the figures are by the author, from specimen number 647 , and of natural size, save where otherwise noted

Piate 6.-Cacops aspidephorus Will. Top view of skull. Specimen number 649.

Prate 7.-Cacops aspidephorus Will. Palatal view of skull. Specimen number 649 .

Plate 8.-Cacops aspidephorus Will. Figure 1, side view of skull; specimen number 649. except posterior part of mandible ; figure 2, upper view of left mandible.

PuAte 9.-Cacops aspidephorus Will. Vertehral column, from right, with sacral ribs.

PIAte 10.-Cacops aspidephorus Will. Figure 1, scapula, with attached cleithrum and clavicle; $a$, from within; $b$, from without; flgure 2, Aspidosaurus sp. Broili, spines of dorsal vertebræ; $a$, from the left; $b$, from in front; figure 3, Desmospondylus anomalus, posterior dorsal vertebræ; $a$, from the left; $b$, intercentrum from below; both figures twice natural size.

Plate 11.-Cacops aspidephorts Will. Figure 1. pectoral girdle from above; figure 2, left humerus, from inner side; figure 3 , the same from outer side: figure 4 , the same from in front; figure 5 , the same from behind.

Puate 12.-Cacops aspidephorus Will. Figure 1, various toe-bones of left hind foot; figure 2, tarsals of same foot; figure 3, carpals and phalanges of left front foot; figure 4, pelvis, from below ; figure 5, twelfth vertebra. from in front, the left pleurocentrum omitted; figure 6 , dorsal shield of same vertebra; $a$, from above; $b$, from below; figure 7 , hypocentrum ; figure 8 . ribs, as numbered, 3 and 5 of the left side, the others from the right.

Plate 13.-Cacops aspidephorus Will. Figure 1, pelvis, from the right; figure 2. left femur. from in front: figure 3. the same. from hehind; figure 4. the same. from within; figure 5 , the same, from without. 


\section{4 s. W. WILLISTON-NEW GENERA OF PERMIAN VERTEBRATES}

Plate 14.-Cacops aspidephorus Will. Figure 1, left tibia, from in front; figure 2, the same, from behind ; figure 3 , the same, from within ; figure 4 , the same, from without; figure 5, left fibula, from behind; figure 6 , the same, from in front; $a$, upper extremity ; figure 7, left radius, from behind ; figure 8, the same, from in front; figure 9, the same, from within; figure 10, left ulna. from in front; figure 11, Dissorophus multicinctus, atlas; $a$, from behind; $b$, from in front; $c$, from the side; $d$. from below; figure 12, anterior hypocentrum, twice natural size.

Plate 15.-Figure 1, genus new, right humerus; $a$, from in front; $b$, from behind; figure 2, Crossotelos Case, left humerus, reversed, from behind; $a$. the same, from in front; $b$, the same, distal end; $c$, the same, proximal end; figure 3, Crossotelos, right humerus of another specimen, reversed. from behind ; figure 4, genus new, right bumerus ; $a$, from in front ; $b$, from behind; $c$, proximal end; figure 5 , genus new, left humerus, from behind; figure 6, Trimerorhachis Cope, left humerus; $a$, from behind; $b$, from in front; figure 7, Diplocaulus Cope, right humerus, from behind.

Plate 16.-Desmosponallus Will. Figure 1, D. anomalus Will., right bumerus; $a$, from side; $b$, from in front; figure $2, D$. anomalıs, tibia; flgure $3, D$. anomalus, radius; figure $4, D$. anomalus, right femur, from behind; figure 5, Desmospondylus, sp. n., left femur, from in front, natural size ; figure 6, $D$. anomalus, fibula ; flgure $7, D$. anomalus, left ilium, from without ; figure 8, D. anomalus, vertebra, from in front; figure $9, D$. anomalus, centrum, from behind; figure 10, the same, from in front; figure 11, the same, from above; figure 12 , the same, from the left side; all figures, save 5 , twice natural size.

P'LATE 17.-Oacops aspidephorus Will. Mounted skeleton; specimen number 647; one-third natural size. 


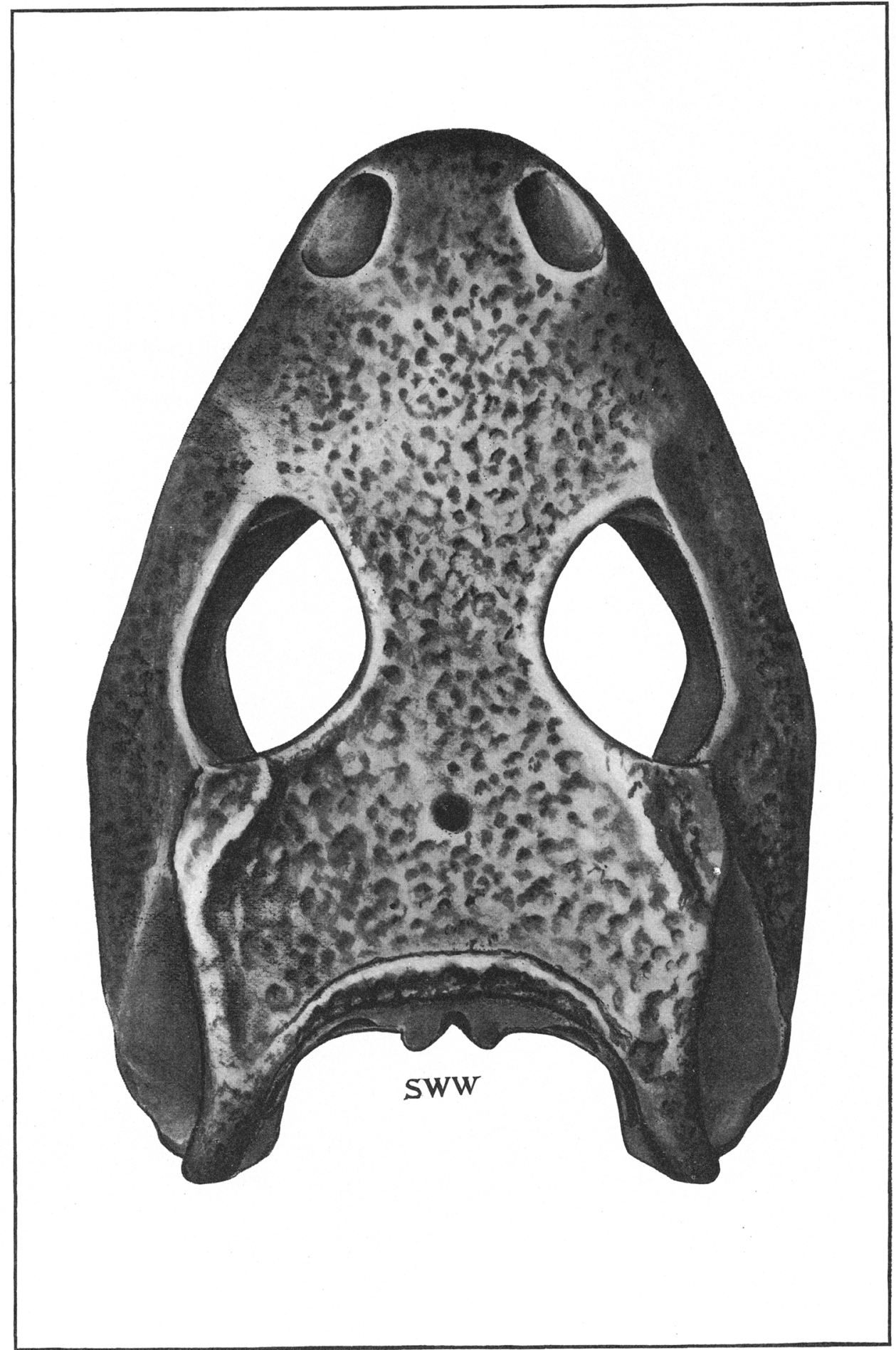




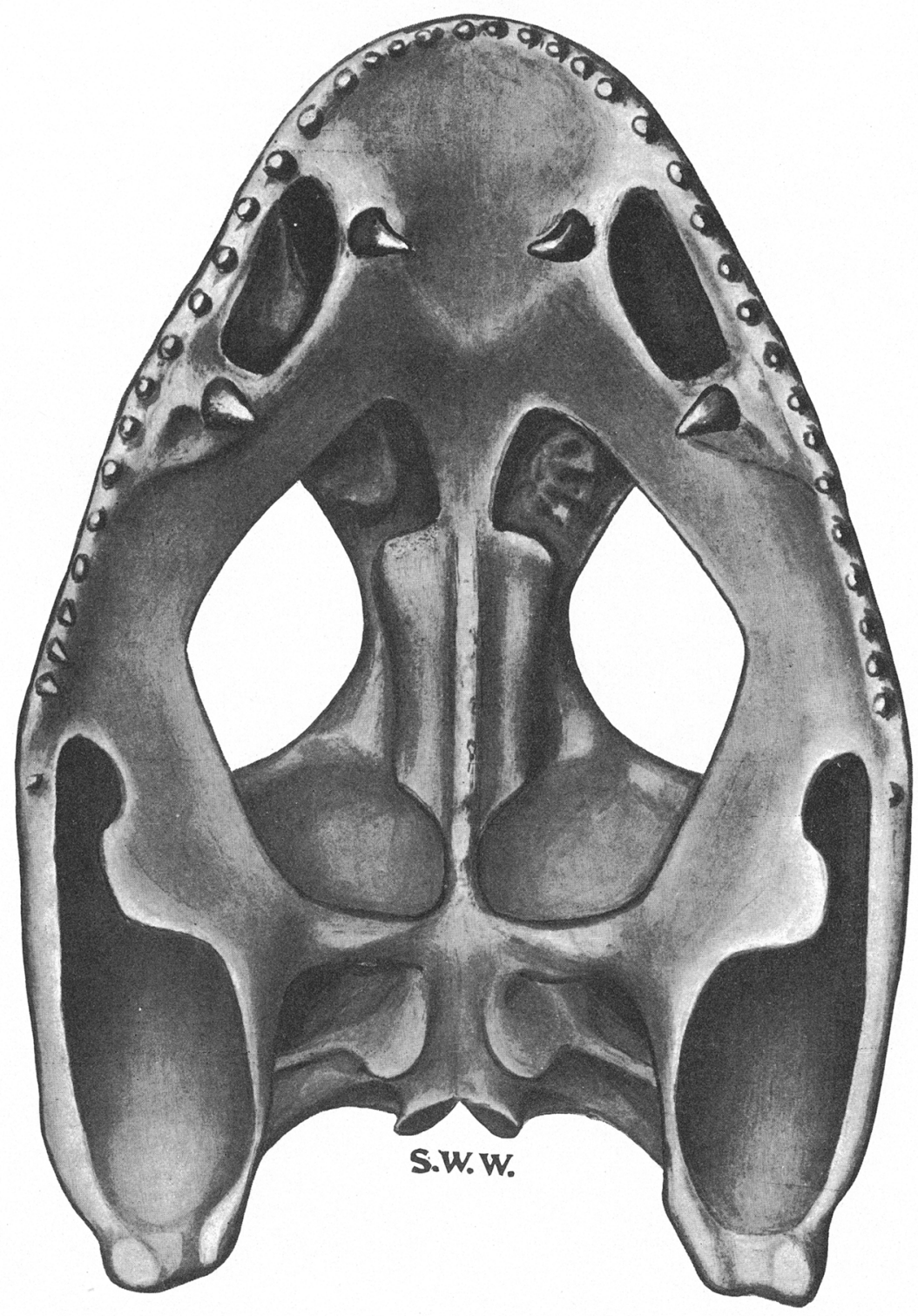




$$
\text { (I) }
$$


Downloaded from gsabulletin.gsapubs.org on August 5, 2015

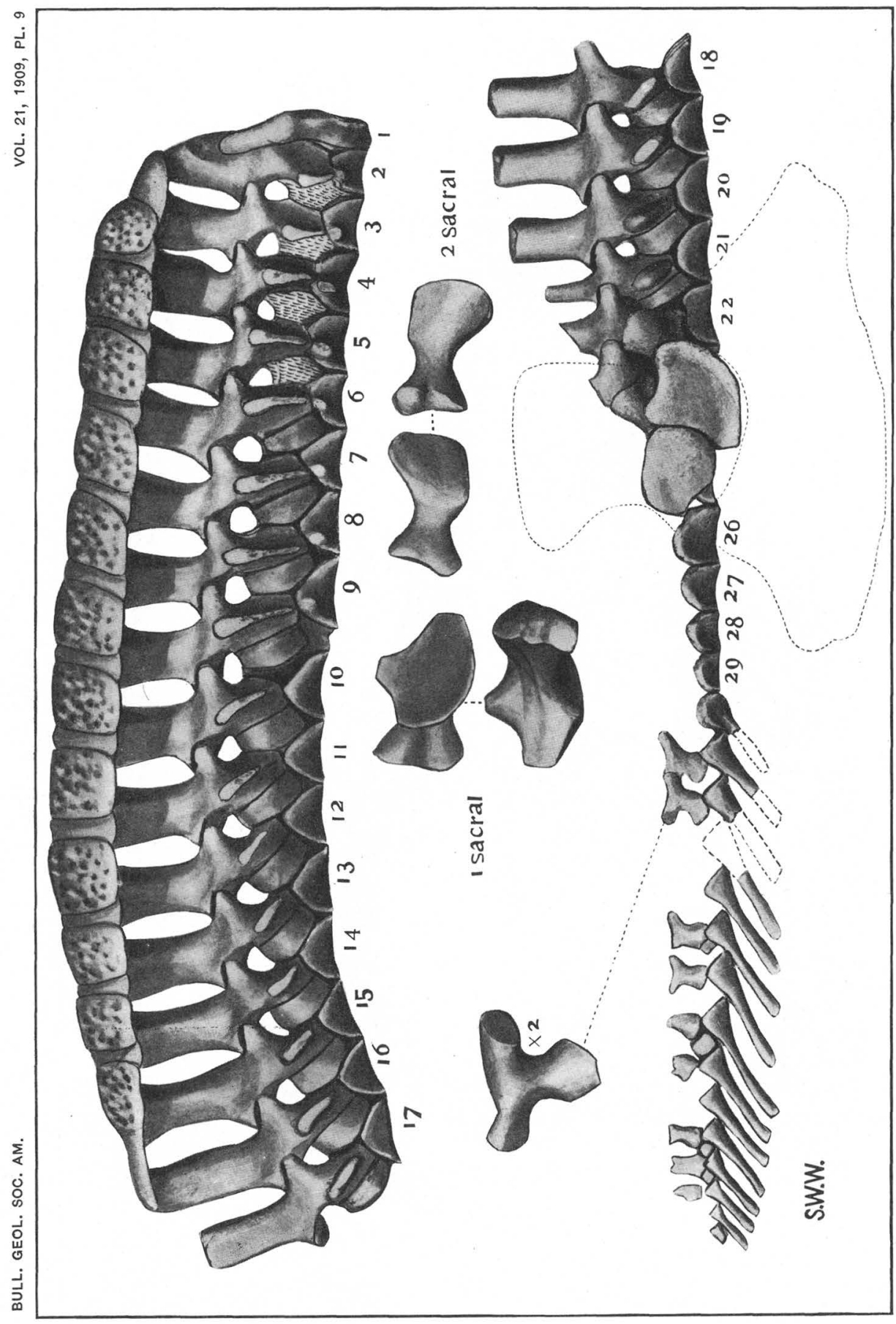


Downloaded from gsabulletin.gsapubs.org on August 5, 2015
oc. AM.

BULL. GEOL. SOC. AM.

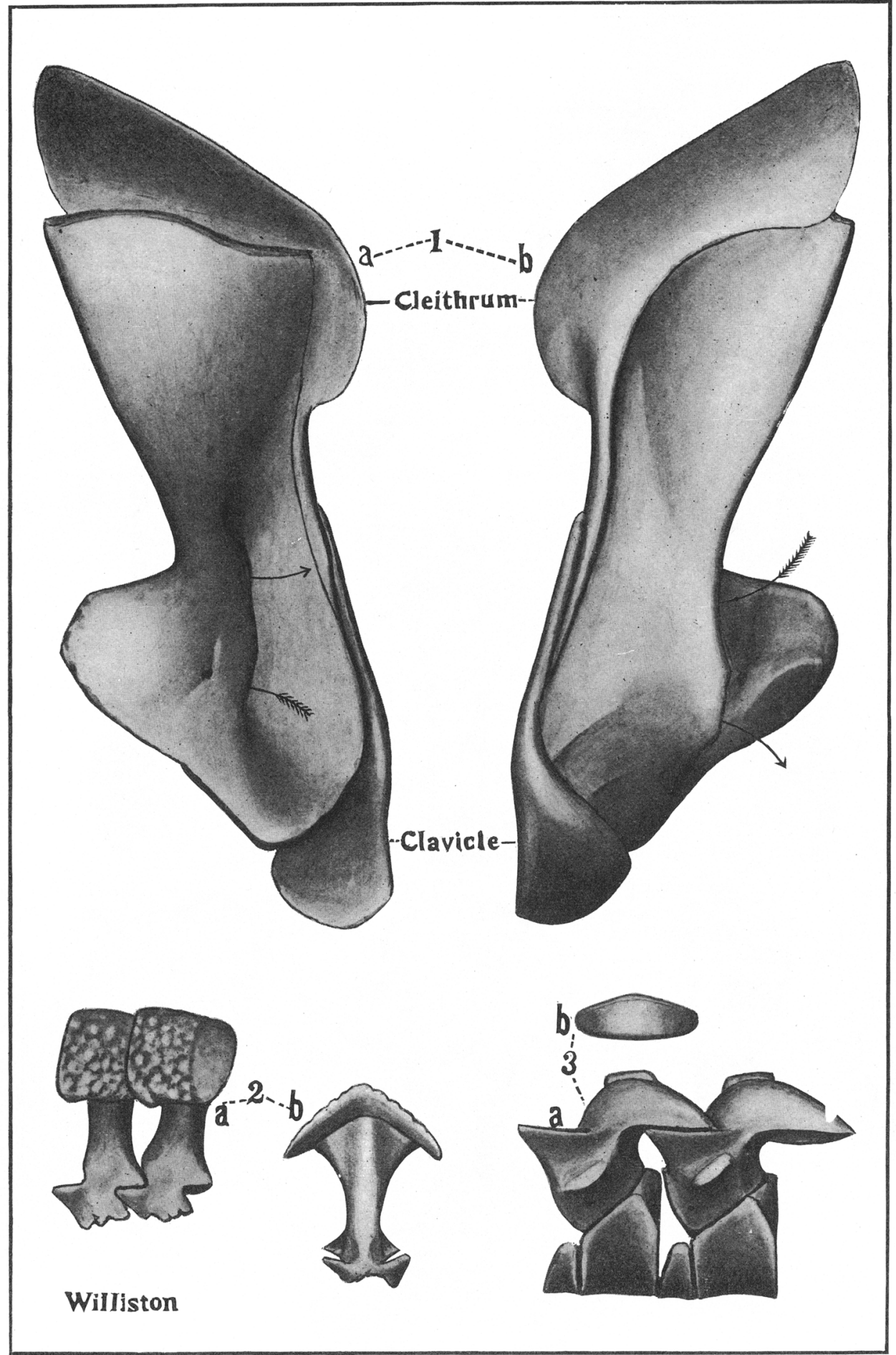

1. CACOPS. 2. ASPIDOSAURUS. 3. DESMOSPONDYLUS 
Downloaded from gsabulletin.gsapubs.org on August 5, 2015

BULL. GEOL. SOC AM.

VOL. 21, 1909, PL. 11
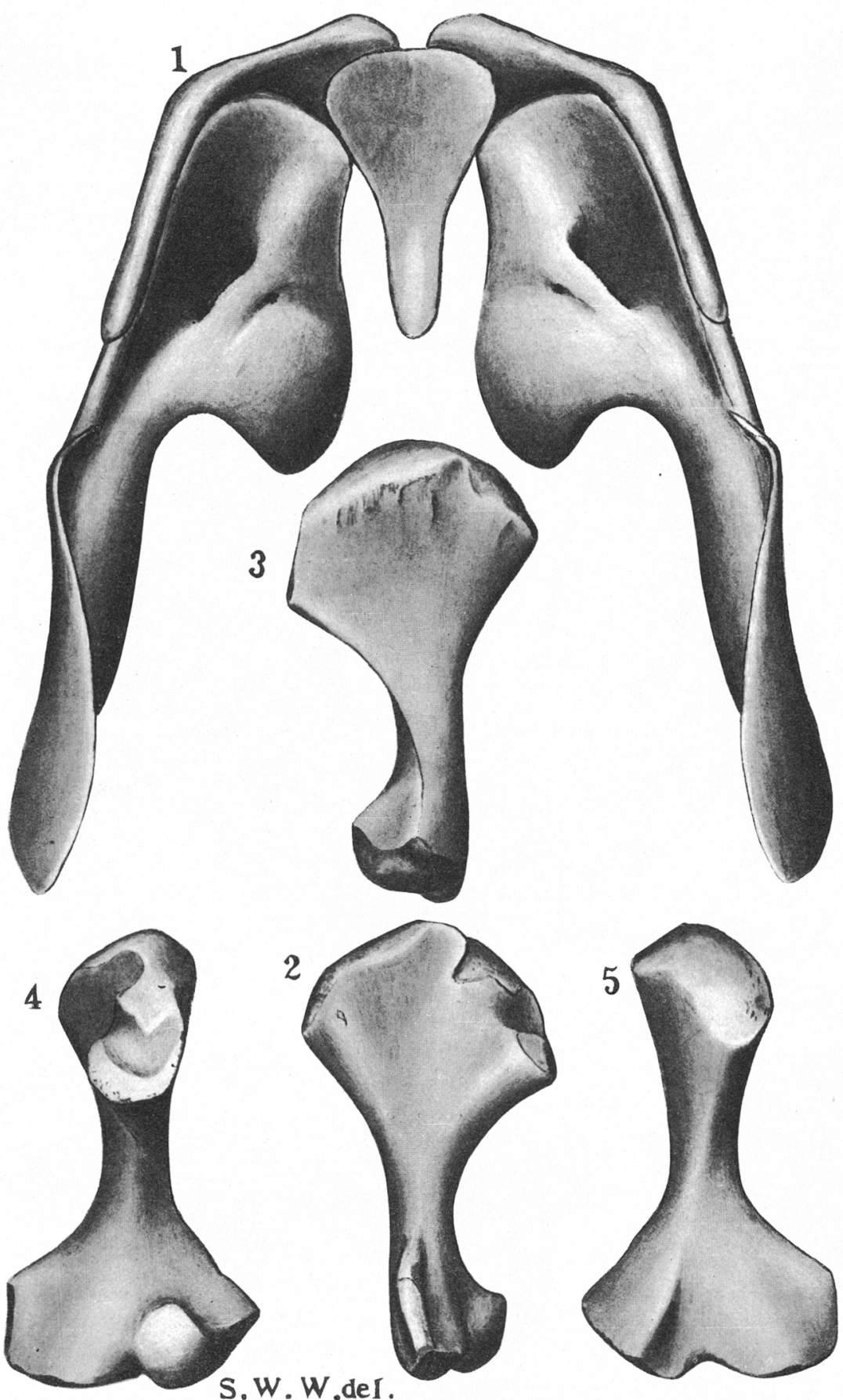


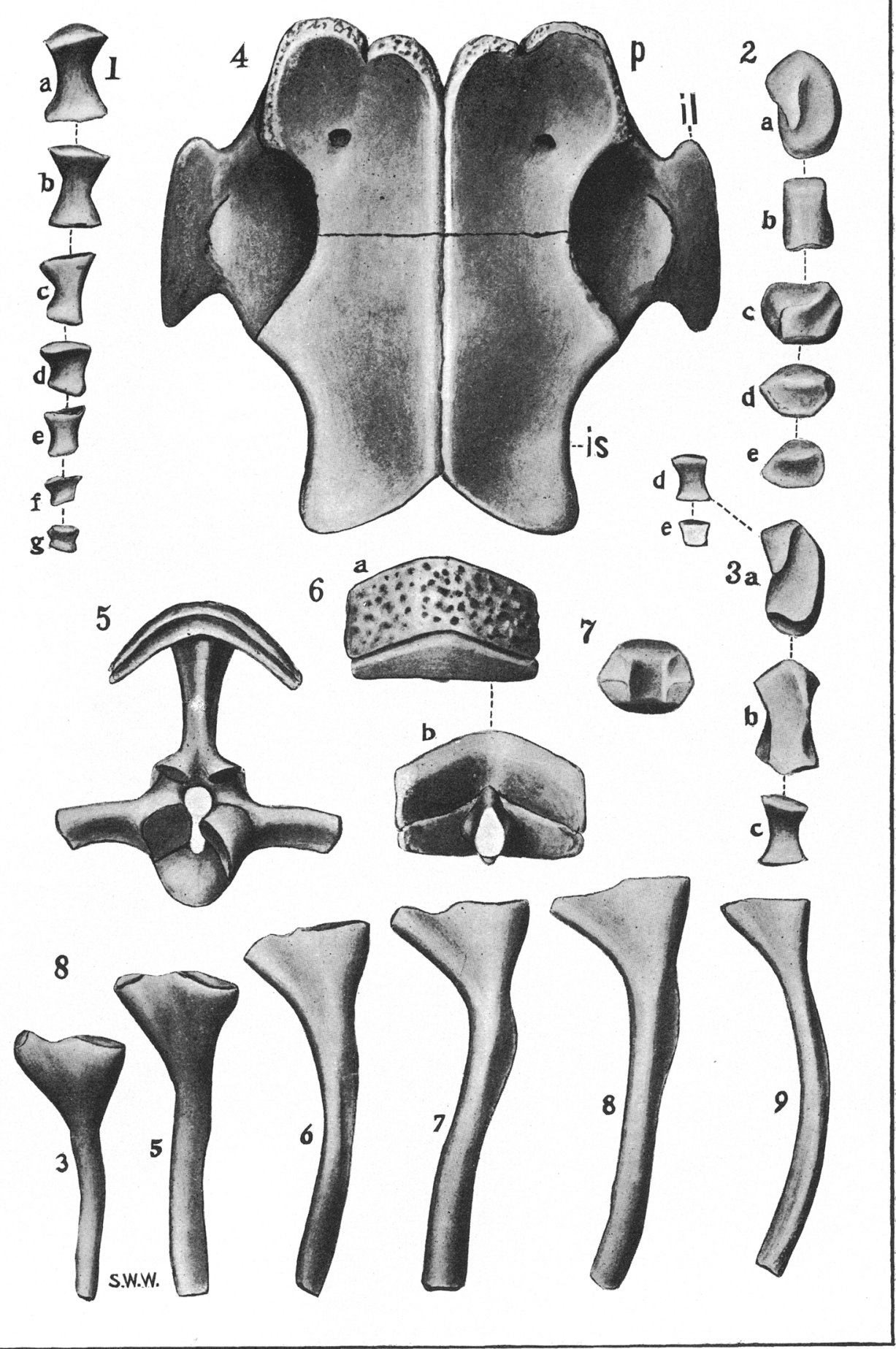




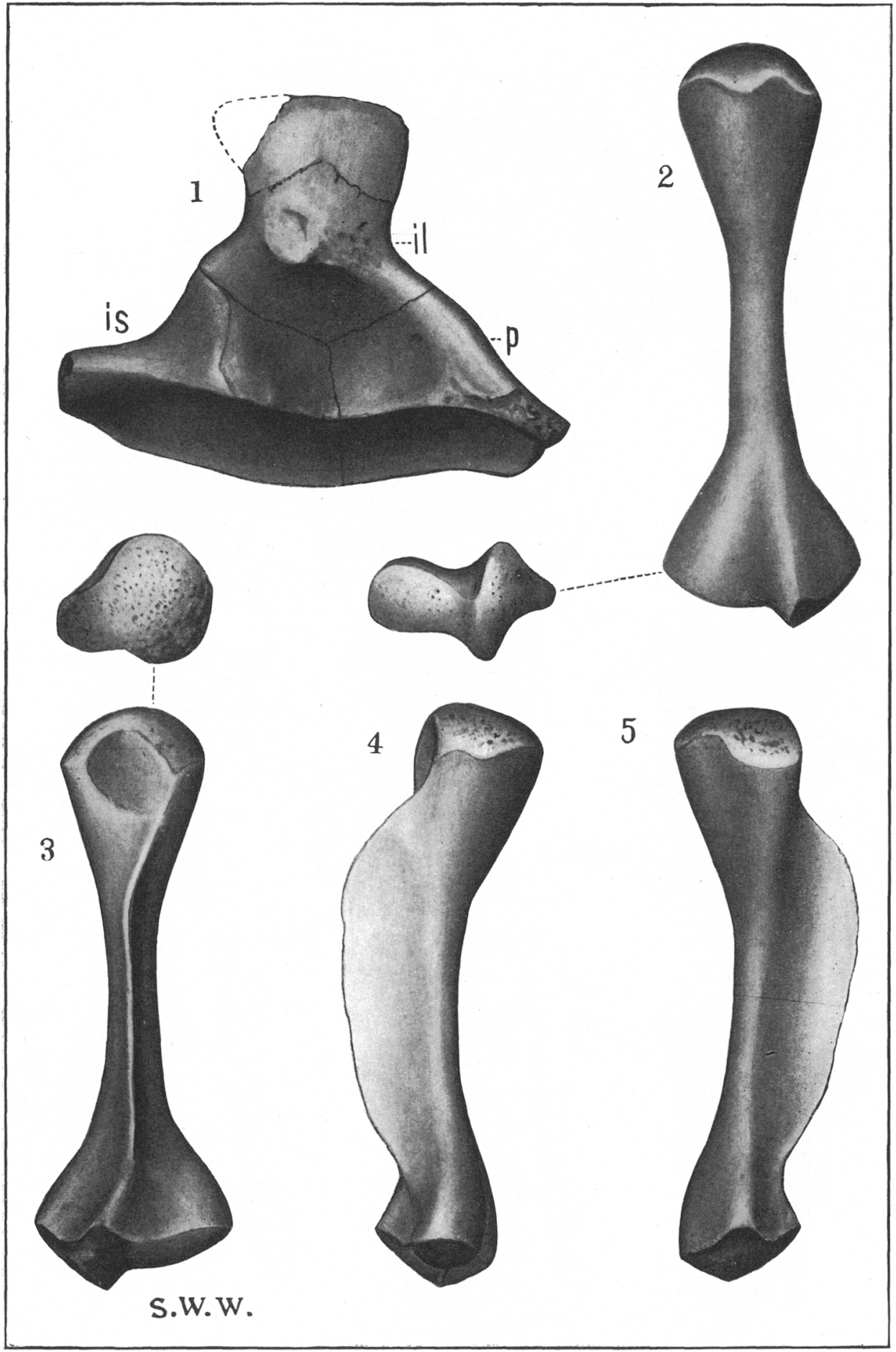




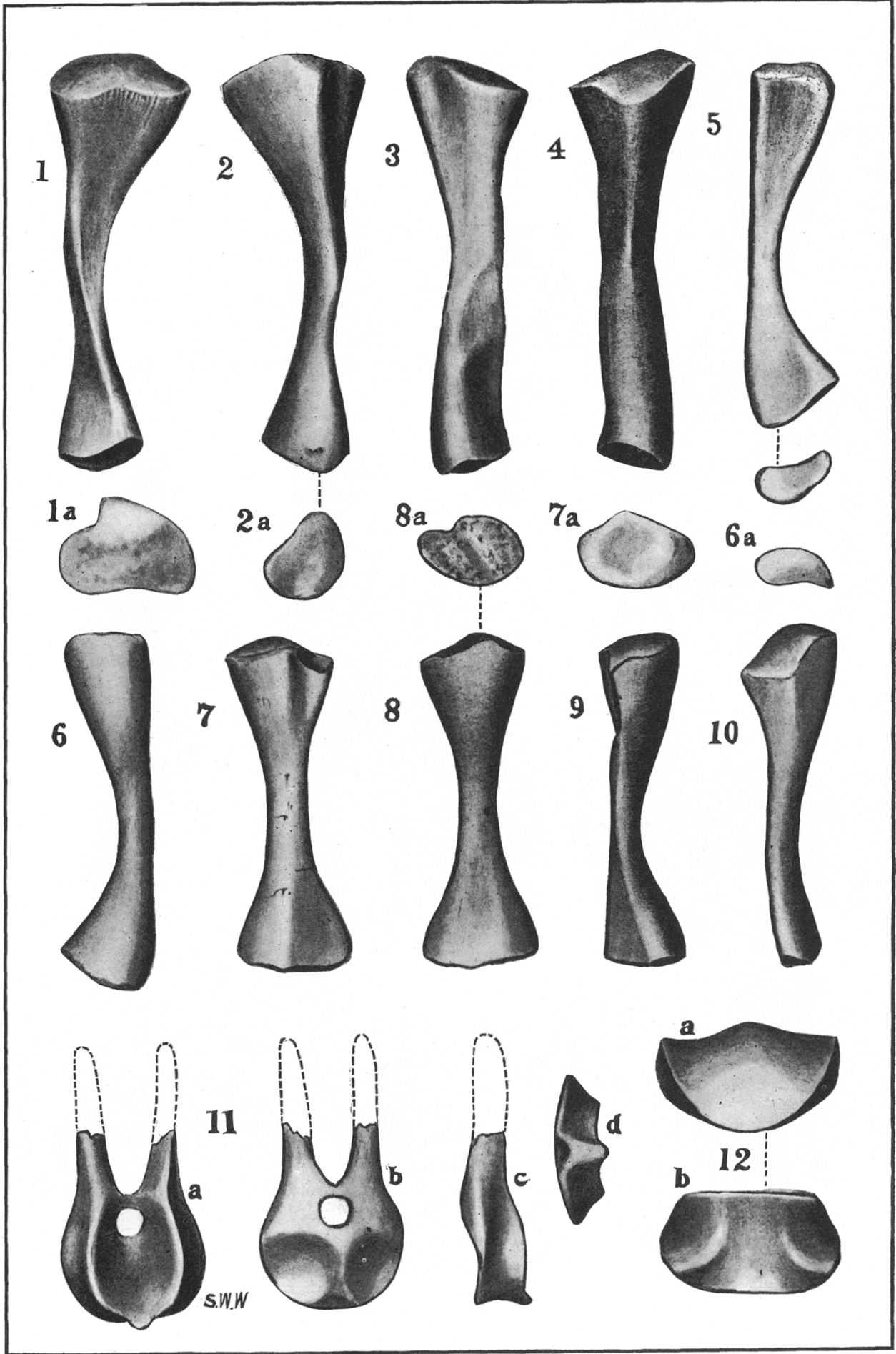



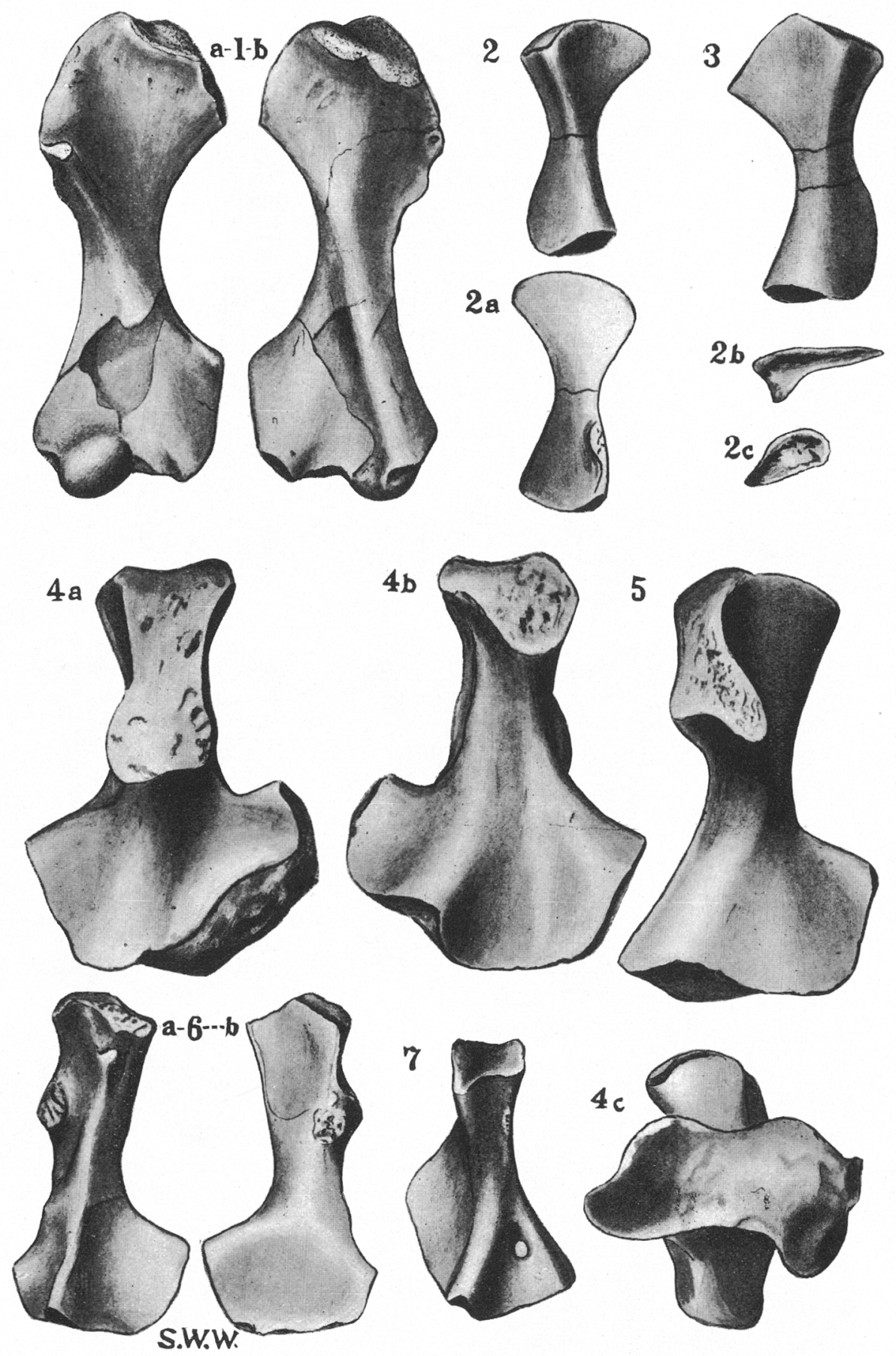

1, 4, 5. NEW GeNera. 2, 3. CROSSOTELOS. 6. TRIMERORHACHIS. 7. DIPLOCAULUS 


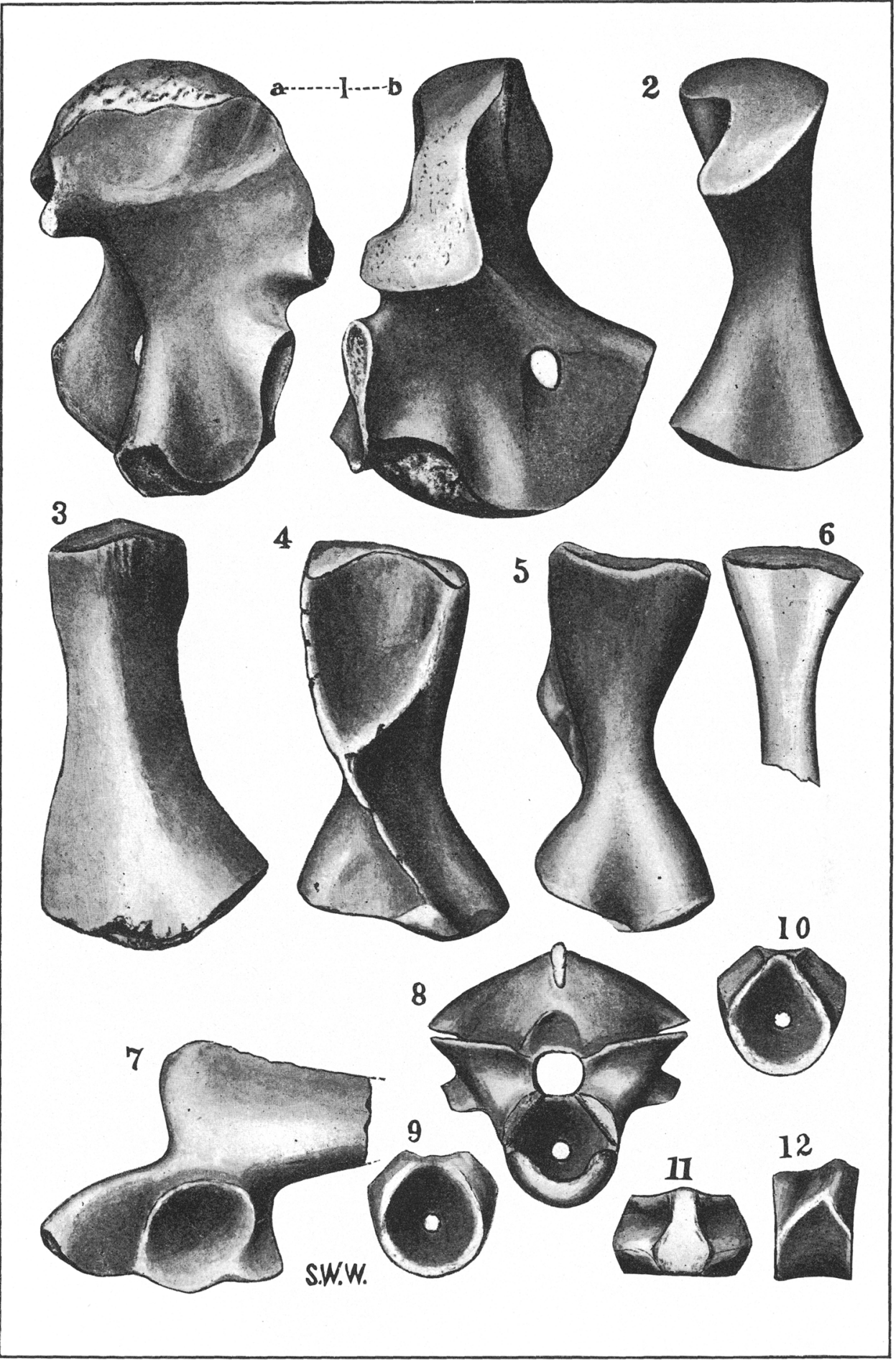




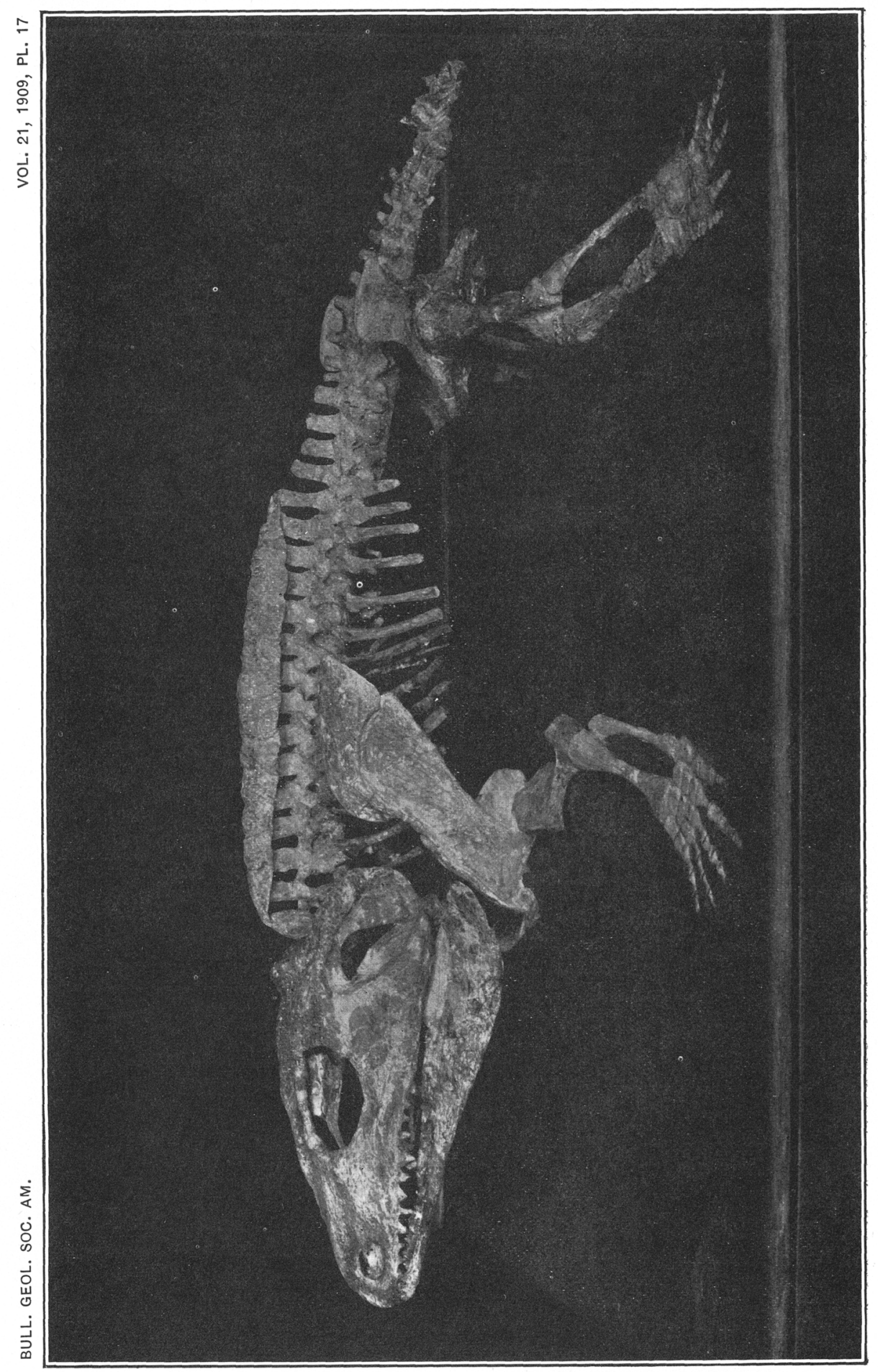




\section{Geological Society of America Bulletin}

\section{Cacops, Desmospondylus; new genera of Permian vertebrates}

S. W. WILLISTON

Geological Society of America Bulletin 1910;21, no.

$1 ; 249-284$

doi: 10.1130/GSAB-21-249

Email alerting services

Subscribe

Permission request click

www.gsapubs.org/cgi/alerts to receive free e-mail alerts when new articles cite this article

click

www.gsapubs.org/subscription s/ to subscribe to Geological Society of America Bulletin

click

http://www.geosociety.org/pub s/copyrt.htm\#gsa to contact GSA

(C) 1910 Geological Society of America

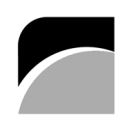

THE GEOLOGICAL SOCIETY OF AMERICA 
Copyright not claimed on content prepared wholly by U.S. government employees within scope of their employment. Individual scientists are hereby granted permission, without fees or further requests to GSA, to use a single figure, a single table, and/or a brief paragraph of text in subsequent works and to make unlimited copies of items in GSA's journals for noncommercial use in classrooms to further education and science. This file may not be posted to any Web site, but authors may post the abstracts only of their articles on their own or their organization's Web site providing the posting includes a reference to the article's full citation. GSA provides this and other forums for the presentation of diverse opinions and positions by scientists worldwide, regardless of their race, citizenship, gender, religion, or political viewpoint. Opinions presented in this publication do not reflect official positions of the Society.

\section{Notes}

(C) 1910 Geological Society of America

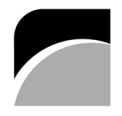

